\title{
1. TECTONIC SETTING OF SERPENTINITE EXPOSURES ON THE WESTERN MEDIAN VALLEY WALL OF THE MARK AREA IN THE VICINITY OF SITE $920^{1}$
}

\author{
Jeffrey A. Karson² and Róisín M. Lawrence²
}

\begin{abstract}
Mantle-derived serpentinized peridotites crop out in a belt approximately $2 \mathrm{~km}$ wide and $20 \mathrm{~km}$ long along the western median valley wall of the Mid-Atlantic Ridge just south of the Kane Transform in the MARK area. Serpentinites extend southward from extensive exposures of gabbroic rocks near the Kane Transform. The belt crops out along approximately half the length of a well-defined ridge segment parallel to a prominent neovolcanic ridge. It terminates in a segment boundary zone to the south marked by a bathymetric depression whose trace extends obliquely off axis northwestward into older crust where serpentinites have also been dredged.

The serpentinites are considered to have been exposed by extreme lithospheric extension along a major crustal detachment, as suggested for mafic plutonic rocks that crop out as an oceanic "core complex" to the north. Gently dipping metamorphic fabrics and fault surfaces in the serpentinites suggest a similar structural history for these two adjacent areas. Consistently oriented high- and low-temperature fabrics along the length of the belt of serpentinized peridotites do not support diapiric uplift as a mechanism for the exposure of these exotic rocks. Gabbroic to diabasic intrusions and overlying basaltic lavas suggest that the serpentinites were exposed by uplift and faulting of upper mantle material that did not develop an extensive overlying magmatic crust as it rose beneath the ridge axis and spread laterally. These types of exposures of hydrated upper mantle material appear to be common elements of oceanic crust formed at slow-spreading ridges with low magma budgets.
\end{abstract}

\section{INTRODUCTION}

Seafloor spreading is accomplished by a combination of mechanical extension and magmatic construction. Along fast-spreading ridges, where nearly continuous axial magma chambers have been identified (Detrick et al., 1987; Toomey et al., 1990), the extrusion of lavas, injection of dikes, and accretion of plutonic materials at depth keep pace with plate separation. For each increment of tectonic extension, magmatic construction will bury or intrude most of the faults and fissures that develop near the surface and accrete new material to the diverging walls of magma bodies at depth.

Along slow-spreading ridge axes, the situation must be very different because a continuous subaxial magma supply is not likely to exist. This contention is supported by studies of the Mid-Atlantic Ridge showing that (1) the neovolcanic zone is discontinuous (Crane and Ballard, 1981; Stakes et al., 1984; Karson et al., 1987), (2) there is a continuous, seismically defined, crust beneath the axial valley (Purdy and Detrick, 1986; Detrick et al., 1990), and (3) seismic activity has been found to occur in the crust and even the mantle beneath the axial valley (Toomey et al., 1988; Kong et al., 1992). Lacking a more or less continuous magma supply during plate separation requires that the existing axial lithosphere be mechanically extended. A similar, but less drastic, situation probably occurs along ridges with intermediate spreading rates (Lewis, 1983; Kappel and Ryan, 1986).

The extent to which mechanical extension and faulting will disrupt any crustal structure produced by magmatic construction will be dictated by the "magma budget," defined as the volume of magmatic material added to the lithosphere per unit of plate separation (Karson and Winters, 1992). At fast-spreading ridges and near hot spots even on very slow-spreading ridges (e.g., Reykjanes Ridge), where the magma budget appears to be relatively high, minimal faulting and

'Karson, J.A., Cannat, M., Miller, D.J., and Elthon, D. (Eds.), 1997. Proc. ODP, Sci. Results, 153: College Station, TX (Ocean Drilling Program).

'Department of Geology, Duke University, Durham, NC 27708-0230, U.S.A. jkarson@geo.duke.edu stretching occur and a relatively thick magmatic crust can be produced. Where the magma budget is low, for example, on many parts of slow-spreading ridges and especially near ridge-transform intersections, stretching, thinning, and tectonic dismemberment of the axial lithosphere and crust will occur.

Commonly, oceanic crust is thought to consist of a series of horizontally layered igneous rock units consisting of surficial basaltic pillow lavas underlain successively by a sheeted diabase dike complex, and several kilometers of gabbroic to ultramafic plutonic rocks over an upper mantle composed of peridotite depleted by partial melting (Moores and Vine, 1971; Casey et al., 1981; Nicolas, 1989). Numerous seismic studies of the oceanic crust formed at a wide range of spreading rates has shown that the seismically defined thickness and velocity structure of oceanic crust worldwide is remarkably uniform (Bratt and Purdy, 1984; Vera et al., 1990). However, there is no unique correlation between rock velocities and seismic velocities determined from marine seismic studies. The distinctive seismic signature of oceanic crust could also be the result of vertical variations in fracture density and porosity as well as alteration superimposed on any pattern of contacts between various rock units (Karson and Fox, 1986; Carlson and Herrick, 1990). Studies of the geology of the median valley walls along slow-spreading ridges with low magma budgets have revealed relationships that are incompatible with any simple, laterally continuous, layered structure. Detailed mapping has suggested a highly heterogeneous assemblage of rock masses in which magmatic rock units are created episodically and are variably thinned by faulting to the extent that they are locally discontinuous (Stroup and Fox, 1981; Karson et al., 1987; Brown and Karson, 1988; Cannat, 1993; Cannat et al., 1995).

Extensive exposures of serpentinized peridotites, inferred to have been derived from the oceanic mantle, have long been known to be present along oceanic fracture zones, especially on slow-spreading ridges (Miyashiro et al., 1969; Bonatti, 1976; Bonatti and Hamlyn, 1981; Fox and Stroup, 1981; Fox and Gallo, 1986; Dick, 1989). Serpentinites also appear to be commonly exposed along the median valley walls of slow-spreading ridges (Aumento and Loubat, 1971; 
Francis, 1981; Karson et al., 1987; Juteau, Cannat, et al., 1990; Cannat et al., 1995). How these rock types can be exposed at the surface is poorly understood and is a continuing topic of debate. The main problem stems from the expectation that oceanic upper mantle rock should ordinarily lie at depths of 5-7 km below the mafic igneous suite of the oceanic crust. Median valley walls of slow-spreading ridges have total relief of as much as $4 \mathrm{~km}$, but they average approximately $1.5 \mathrm{~km}$ (Shih, 1980). They are characterized by closely spaced, faults with vertical separations that are typically less than $100-200 \mathrm{~m}$. Exposures of such deep-level rocks by such minor faulting suggest that in some places serpentinized upper mantle rocks must occur at very shallow crustal levels.

In addition to present-day seafloor exposures, the internal structure of some ophiolite complexes provides additional insights into the geology of this type of oceanic crust. In particular, ophiolites of the Appennines and Western Alps have serpentinites that are overlain directly by basaltic lavas or sedimentary breccias, indicating that they once cropped out on the seafloor (e.g., Lagabrielle and Cannat, 1990).

Several mechanisms have been proposed to account for the exposure of deep crustal and upper mantle rocks on the seafloor: (1) serpentinite diapirism (Bonatti and Hamlyn, 1981; Francis, 1981); (2) diapirism with compressional tectonics (Bonatti, 1976); (3) detachment faulting (Karson et al., 1987; Karson, 1990); and (4) passive uplift and alteration of subaxial mantle without creation of an overlying magmatic crust (Hess, 1962; Karson, 1990; Brown and Karson, 1988; Cannat, 1993; Cannat et al., 1995). In this paper, we summarize detailed surface studies and drilling results that together shed new light on these hypotheses.

\section{THE MARK AREA}

The MARK area (Fig. 1) can be divided into three spreading segments on the basis of seismic properties of the median valley crust (Purdy and Detrick, 1986; Detrick et al., 1990), magnetic anomaly patterns (Schulz et al., 1988), residual gravity anomaly patterns (Lin et al., 1990; Morris and Detrick, 1991), and surface geology (Karson et al., 1987; Mével et al., 1991). The median valley is about $30 \mathrm{~km}$ wide, is therefore spreading at a full-rate of $2.7 \mathrm{~cm} / \mathrm{yr}$ (Purdy et al., 1979; Schulz et al., 1988), and has formed in about 1 m.y. Significant variations in the morphology and geology of the rift valley occur between the spreading segments, even in this $100 \mathrm{~km}$ interval of the Mid-Atlantic Ridge (Karson et al., 1987; Brown and Karson, 1988; Kong et al., 1988; Karson and Winters, 1992).

The northern segment extends from the Kane Transform south for about $35 \mathrm{~km}$ to approximately $23^{\circ} 15^{\prime} \mathrm{N}$ latitude (Fig. 1). It is characterized by highly asymmetrical cross-sectional morphology and distribution of rock types. We briefly review the geology of this area because it is nearby and similar in terms of its structural style to the serpentinite exposures described in detail below.

The western wall of the northern cell is dominated by widespread exposures of variably deformed and metamorphosed gabbroic rocks cut by low-angle $\left(30^{\circ}-50^{\circ}\right.$ dipping) faults and shear zones (Karson and Dick, 1983; Karson et al., 1987; Karson and Lawrence, this volume). Fluid inclusions in the metagabbros were formed at a crustal depth of about $2 \mathrm{~km}$ and temperature of about $700^{\circ} \mathrm{C}$, probably beneath the floor of the median valley (Kelley and Delaney, 1987). Two kilometers of overlying basalts and dikes are inferred to have been tectonically removed from this region. At least an additional $2 \mathrm{~km}$ of vertical uplift is required to bring material originally formed beneath the median valley floor to its present position on the median valley wall. In contrast, the eastern median valley wall is lower, less steep, and has only exposures of block-faulted pillow basalts (Fig. 1). Thus, it appears that a large amount of highly asymmetrical, nearly amagmatic, tectonic extension has affected this spreading segment over the course of the last $1 \mathrm{~m} . \mathrm{y}$.

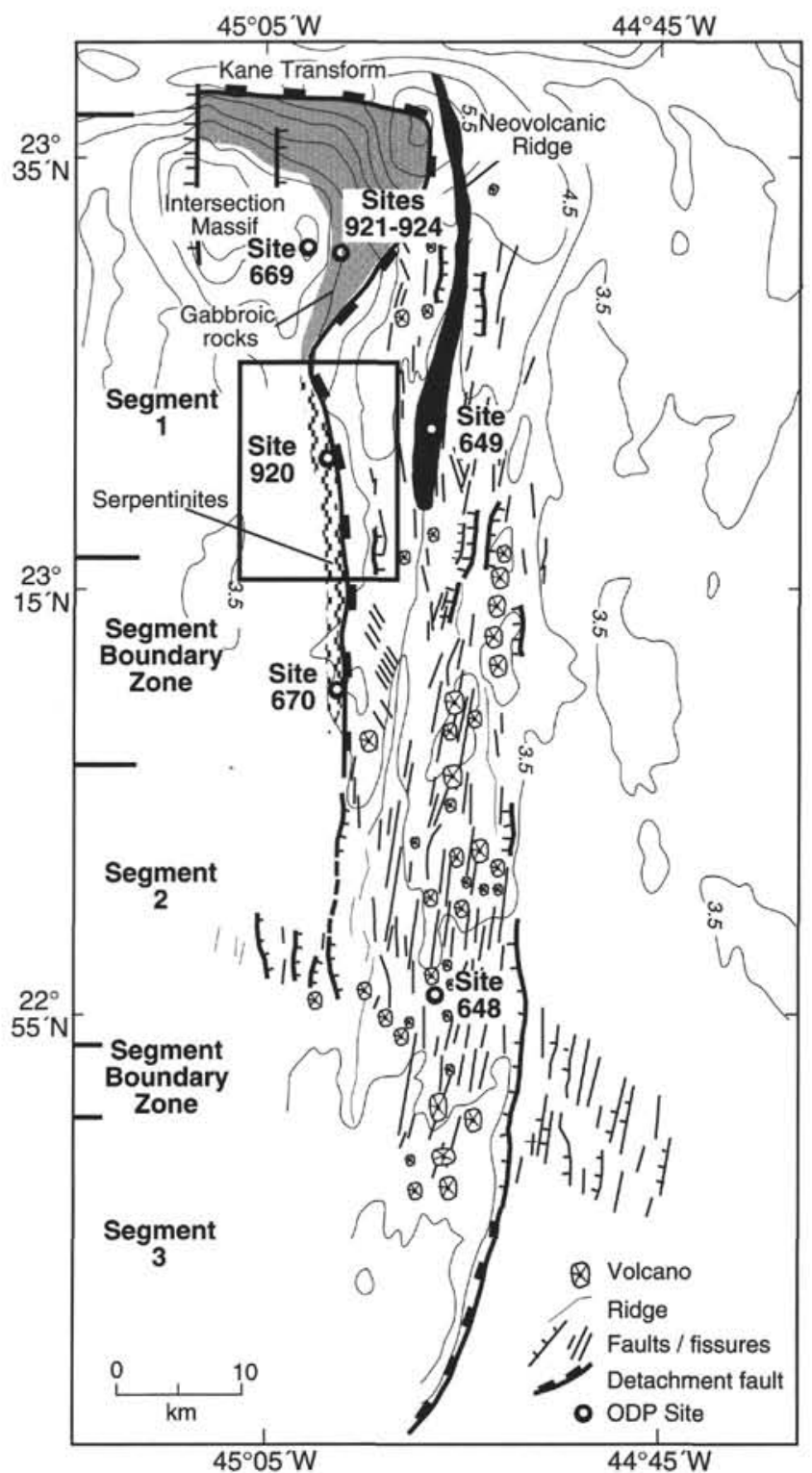

Figure 1. Generalized tectonic map of the MARK area, Mid-Atlantic Ridge at $22^{\circ}-24^{\circ} \mathrm{N}$ latitude. The box indicates the location of the serpentinite outcrop area drilled at Site 920 during Leg 153 and shown in more detail in Figures 2 and 3. Note that this area is part of a much more extensive belt of serpentinites that crop out along the western median valley wall of the rift valley. The serpentinite belt has been identified where it was crossed by several submersible transects. The highly magnetized serpentinites are thought to be responsible for a prominent magnetic anomaly lineament that lies along this belt (Brown and Karson, 1988). Gray pattern = gabbro outcrop area near the intersection with the Kane Transform. Zigzag pattern = serpentinite outcrop area inferred from submersible crossings (Alvin: 1682, 1684, 1689, 2577; and Nautile: HS-12, 13, 19). Contours are in kilometers below sea level. After Detrick et al. (1988), Karson et al. (1987), Mével et al. (1991), and Cannat, Karson, Miller, et al. (1995). Ridge axis segments and boundaries are indicated along the left edge of the map.

The highly extended terrain of the western wall appears to have evolved as an "oceanic core complex" with a major detachment fault zone that cut through the full thickness of the crust and perhaps the entire axial lithosphere. The detachment fault zone may have started out as a steep fault in the median valley floor that flattened somewhat with subsequent extension. The footwall of the detachment surface is 
now disrupted by steeper faults of the median valley wall in a pattern that is similar to that of Cordilleran metamorphic core complexes (Wernicke and Burchfiel, 1982; Lister and Davis, 1989). Rotations of blocks bounded by the later faults may have either steepened or flattened the present fault surfaces. Such "oceanic core complexes" may be common near ridge-transform intersections and at other ridge segments where the magma budget is very low.

Paradoxically, the northern segment appears to be the most volcanically active region of the MARK area. A median neovolcanic ridge ( $400 \mathrm{~m} \times 4 \mathrm{~km} \times 40 \mathrm{~km}$ ) runs the length of the segment (Fig. 1), but this edifice was constructed only about $5000 \mathrm{yr}$ ago, probably after a protracted period of crustal stretching (Karson et al., 1987; Brown and Karson, 1988; Karson, 1990). The active black-smoker hydrothermal vents of the Snake Pit hydrothermal area are situated at the top of this ridge, and they may be related to a small magma chamber or young pluton at depth. Seismic reflection data showed no evidence of an East Pacific Rise-type magma chamber refection beneath this area, but small magma bodies might not be imaged in such rough terrain (Detrick et al., 1990). Magmatism in this segment therefore appears to have been discontinuous over at least the past 0.5 m.y. Studies of the crustal cross section exposed along the southern wall of the Kane Transform just to the north indicate that crustal stretching and intermittent magmatism have persisted for at least the past $4 \mathrm{~m}$.y. (Auzende et al., 1993).

The northern spreading segment is separated from the symmetrical spreading segment to the south by a poorly known segment boundary zone (Fig. 1). Morphologically similar segment boundaries are typical of other segments of the Mid-Atlantic Ridge (Purdy et al., 1990; Sempéré et al., 1990; Grindlay et al., 1991). They have been referred to as "zero-offset transforms" (Schouten and White, 1980), "discordant zones" (Grindlay et al., 1991), or simply "ridge axis discontinuities" (Macdonald et al., 1988). In the MARK area, variations in structural geometry of adjacent segments require that these regions contain oblique-slip or strike-slip fault zones that permit different normal fault geometries and/or rates of tectonic extension in adjacent segments. These are similar to "accommodation zones" or "transfer zones" found in continental rifts (Rosendahl et al., 1986; Morley et al., 1990). In the MARK area, these types of structures are a kinematic requirement of the along-strike (north-to-south) changes from eastdipping asymmetrical detachment faults to symmetrical high-angle normal faulting to west-dipping detachment faulting (Karson and Winters, 1992). The accommodation zones are at present poorly defined in terms of surface geology, but they must be significantly different from overlapping spreading centers (Macdonald and Fox, 1983), deviations from axial linearity (devals: Langmuir et al., 1986), and small non-overlapping offsets (SNOOs: Batiza and Margolis, 1986) of the East Pacific Rise. The East Pacific Rise discontinuities appear to be boundaries between magmatic cells, whereas the accommodation zones of the MARK area are mechanical discontinuities (i.e., fault zones) with complex fault structures and protracted (perhaps hundreds of thousands of years) deformation histories (Karson, 1991; Karson and Winters, 1992). These types of discontinuities are integral parts of the segmentation of slow-spreading ridges.

The segment boundary at the southern end of the northern segment is characterized by a bathymetric low and a cross-axis profile that lacks a well-defined median valley (Karson et al., 1987). It has closely spaced northwest-trending faults and fissures and is associated with serpentinite exposures (Brown and Karson, 1988; Kong et al., 1988). This part of the ridge axis also corresponds to a crustal seismic discontinuity (Purdy and Detrick, 1986). The trace of this depression extends off axis into older crust as a distinct bathymetric lineament trending northwest, oblique to the spreading flow lines (Gente et al., 1995). This corresponds to a Residual Bouguer Mantle Anomaly (RBMA) high (Deplus et al., 1992) and outcrops of serpentinites in a regional-scale pattern of lineaments oriented obliquely to the spreading direction (Cannat et al., 1995).
These relationships suggest that the processes responsible for the exposure of serpentinites along the median valley wall persist in time and migrate along the ridge axis. The serpentinite outcrops could mark areas of thin crust resulting from a lack of basaltic melt production and major faulting (Brown and Karson, 1988; Cannat, 1993; Cannat et al., 1995).

Recent advances in imaging the oceanic crust with seismic reflection techniques have revealed a complex internal fabric of reflectors in the middle and lower crust produced at slow-spreading ridges (Mutter and Karson, 1992; Morris et al., 1993). Overall, these define an anastomosing array of reflectors that dip parallel, orthogonal, and oblique to spreading flow lines. These suggest that major crustal detachments may be common elements of slow-spread crust and that the accommodation zones may be essentially lateral ramps linking major crustal detachments (Mutter and Karson, 1992).

In this paper, we consider the outcrop and shallow subsurface geology of the serpentinite belt of the MARK area in the context of local ridge segmentation and seafloor spreading processes along slowspreading ridges.

\section{PREVIOUS STUDIES OF SERPENTINITE EXPOSURES IN THE MEDIAN VALLEY OF THE MARK AREA}

Serpentinite outcrops were first discovered on the western median valley wall of the MARK area (Figs. 1-3) at $23^{\circ} 10^{\prime} \mathrm{N}$ and $23^{\circ} 20^{\prime} \mathrm{N}$ latitude during a series of Alvin dives (1682, 1684, and 1689) in 1985. Nearby areas were crossed with the ANGUS deep-towed camera sled (Karson et al., 1987). The JOIDES Resolution was drilling on Leg 109 when the serpentinites were found and only a few days later, drilling at Site 670 penetrated to a depth of approximately $100 \mathrm{~m} \mathrm{(7 \%}$ recovery) in rubbly serpentinites at $23^{\circ} 10^{\prime} \mathrm{N}$ (Detrick, Honnorez, Bryan, Juteau, et al., 1988).

Additional dives (HS 12,13, 19, and 20) were later made near $23^{\circ} 20^{\prime} \mathrm{N}$ in 1988 with Nautile (Mével et al., 1991). During Leg 153, Holes 920B and 920D were drilled near dive HS-13 to depths of 126 and $200 \mathrm{~m}$, respectively (38\% and $47 \%$ recovery). During this cruise, a vertically oriented video camera on the end of the drill string was used to survey the area around Site 920 (Fig. 4) and look for gently sloping rock benches on which to deploy a hard-rock guide base (Cannat, Karson, Miller, et al., 1995).

Most recently, Alvin dive 2577 revisited Site 920 to observe the drilling site and to collect oriented samples to constrain paleomagnetic reconstructions (J.A. Karson, S.D. Hurst, R.M. Lawrence, and SMARK Cruise Participants, 1995, unpubl. data). Other important background data for the area were collected as part of a site survey for Ocean Drilling Program (ODP) Legs 106 and 109 and include regional SeaBeam bathymetric coverage (Detrick et al., 1988), SeaMARC I side-scan sonar swaths in the axial region of the median valley (Kong et al., 1988), and regional surface ship magnetic data (Schulz et al., 1988).

The serpentinite outcrops of this area have been briefly described in Karson et al. (1987) and Mével et al. (1991). In the following descriptions we expand upon these initial reports to develop a more complete view of this important terrain. Most of the following information comes from the $23^{\circ} 20^{\prime} \mathrm{N}$ area (Figs. 2,3 ), but some additional data from the $23^{\circ} 10^{\prime} \mathrm{N}$ area are also included.

\section{SERPENTINITE OUTCROPS IN THE MARK AREA Morphology}

The serpentinites crop out on the western median valley wall of the MARK area between relatively young basaltic pillow lavas of the 
Figure 2. Bathymetric map of the area around Site 920 on the western wall of the Mid-Atlantic Ridge in the MARK area from SeaBeam bathymetry (Detrick et al., 1988). See Figure 1 for location. The bold line to the eastern edge of the map shows the SeaMARC 1 path (see Fig. 3 for interpretation and geology).

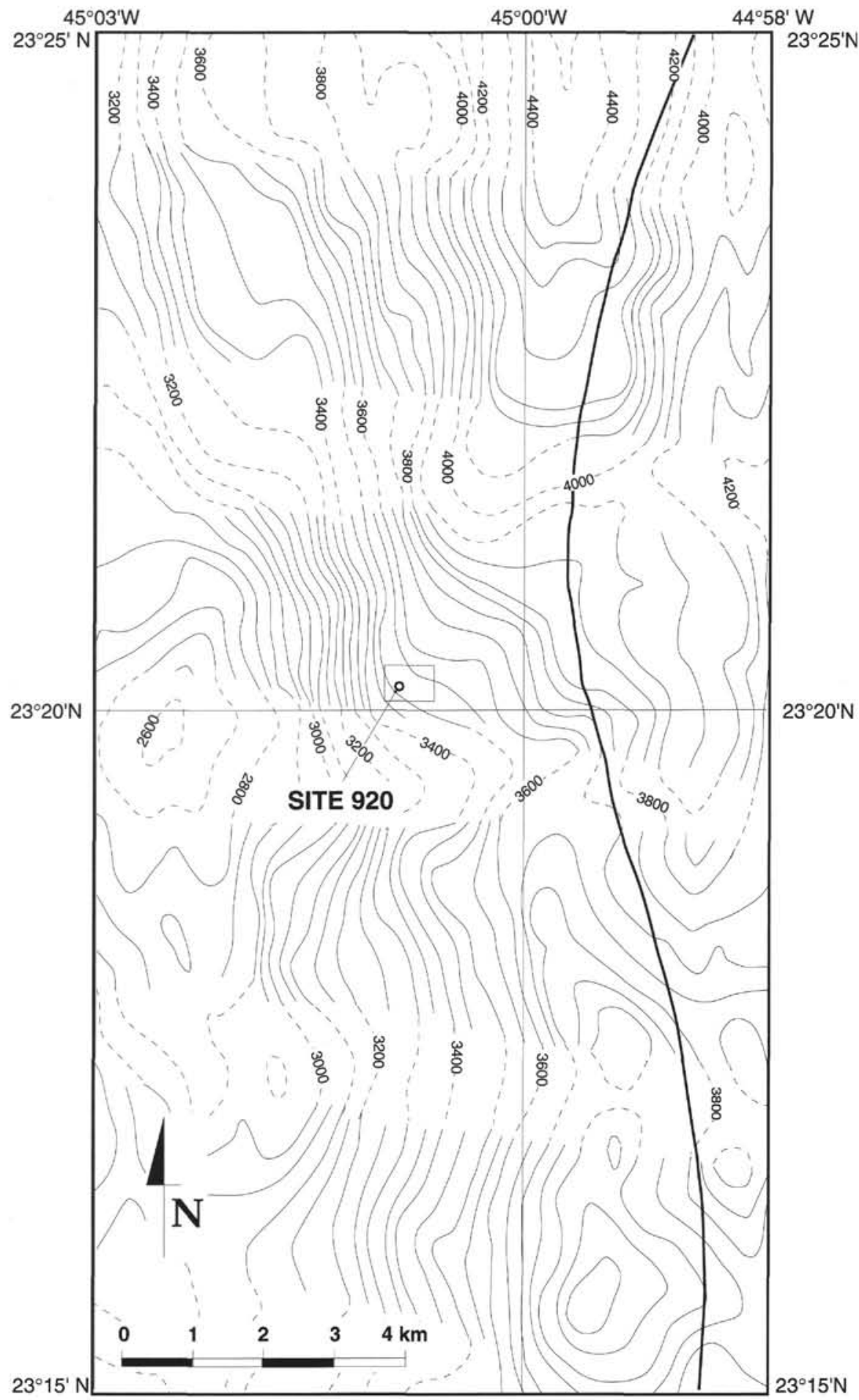

median valley floor and older, more heavily sedimented basalts of the crest of the median valley wall to the west. The median valley wall is not regular and linear as it is along many other parts of the Mid-Atlantic Ridge (Purdy et al., 1990). Instead, it is marked by numerous closed contour depressions and hills a few kilometers across. The largest of the hills is at approximately $23^{\circ} 19^{\prime} \mathrm{N}$ ("Pink Hill": Mével et al., 1991). Site 920 and several dive transects along which serpentinites were sampled are located on the median valley wall just east of this hill.

Side-scan sonar records (Fig. 3) show an abrupt change in backscatter patterns at the base of the western median valley wall. Hum- mocky reflector patterns typical of basaltic pillow lavas end westward along a swath of strongly lineated terrain that extends westward beyond the limit of the survey. The lineated terrain appears to be intensely faulted and fissured material defining the lower slope of the median valley wall. Smooth conical hills with summit depressions probably represent individual volcanic edifices (Kong et al., 1988). Locally, some of these conical hills are superimposed on the lineated terrain, suggesting that at least some eruptions occurred in the lineated terrain (Fig. 3). The median valley wall has average slopes of $20^{\circ}-$ $30^{\circ}$, but it has a stair-step morphology with steep fault-line scarps up to $200 \mathrm{~m}$ high separating very gently sloping terraces $100-300 \mathrm{~m}$ 

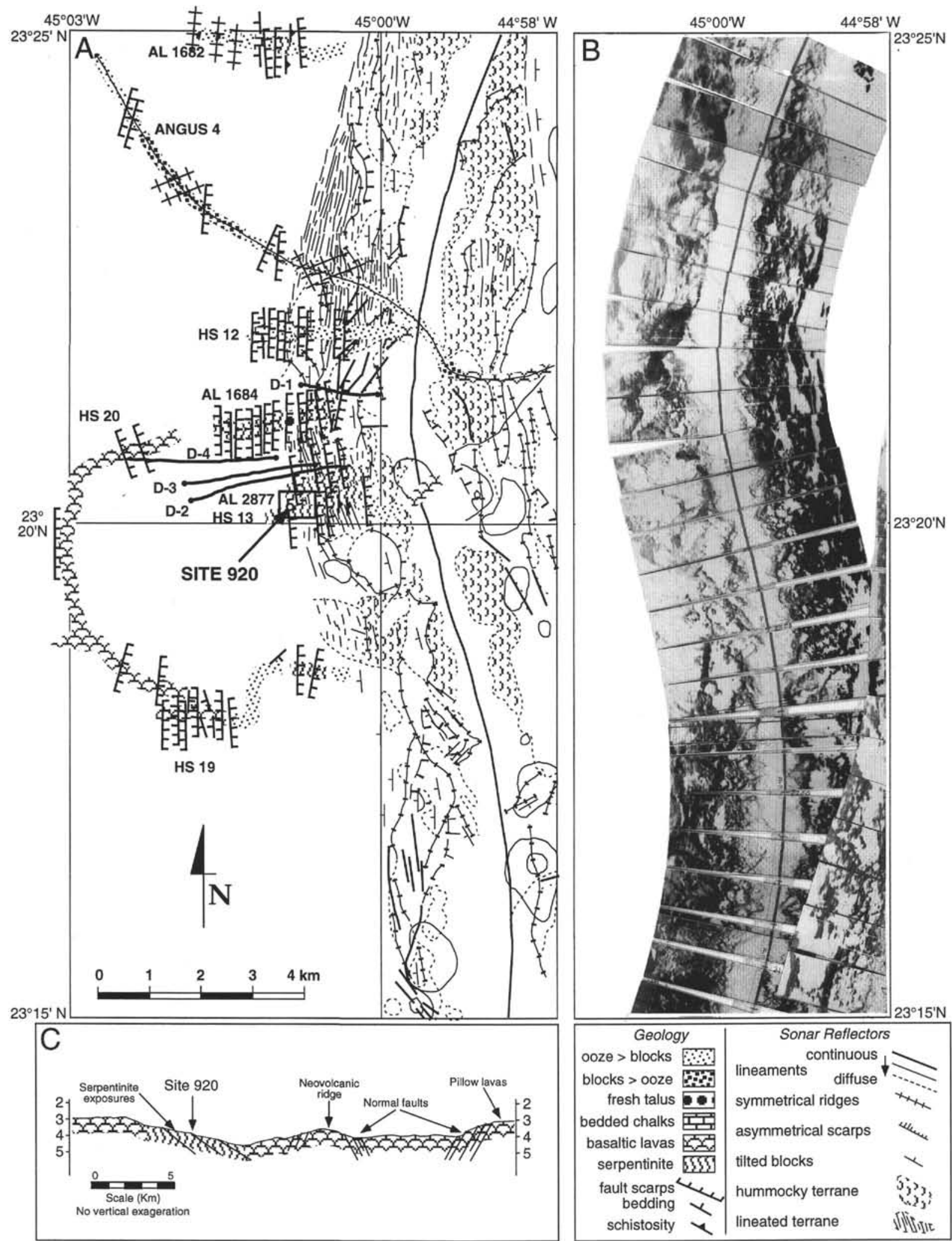

Figure 3. A. Geology in the vicinity of Site 920. Data from SeaMARC I side-scan sonar (Kong et al., 1988); ANGUS deep-towed camera runs (Karson et al., 1987; Winters, 1989), Alvin dives 1682, 1684, 2877 (Karson et al., 1987; Winters, 1989; J.A. Karson, S.D. Hurst, R.M. Lawrence, unpubl. data); Nautile dives HS-12, 13, 19, 20 (Mével et al., 1991), and dredges D1-D3 (Gente et al., 1989). The box at Site 920 shows the extent of an ODP video camera survey (see Fig. 4). Note the blank area along which no data were collected in the near-field along the SeaMARC I path along the eastern edge of the map area. B. Photomosaic of the SeaMARC I swath covering the area shown in A. C. Cross section of the terrain and surface geology across the Mid-Atlantic Ridge median valley near Site 920, compiled from submersible and deep-towed camera data (after Winters, 1989). 
A VIT Camera, surficial geology

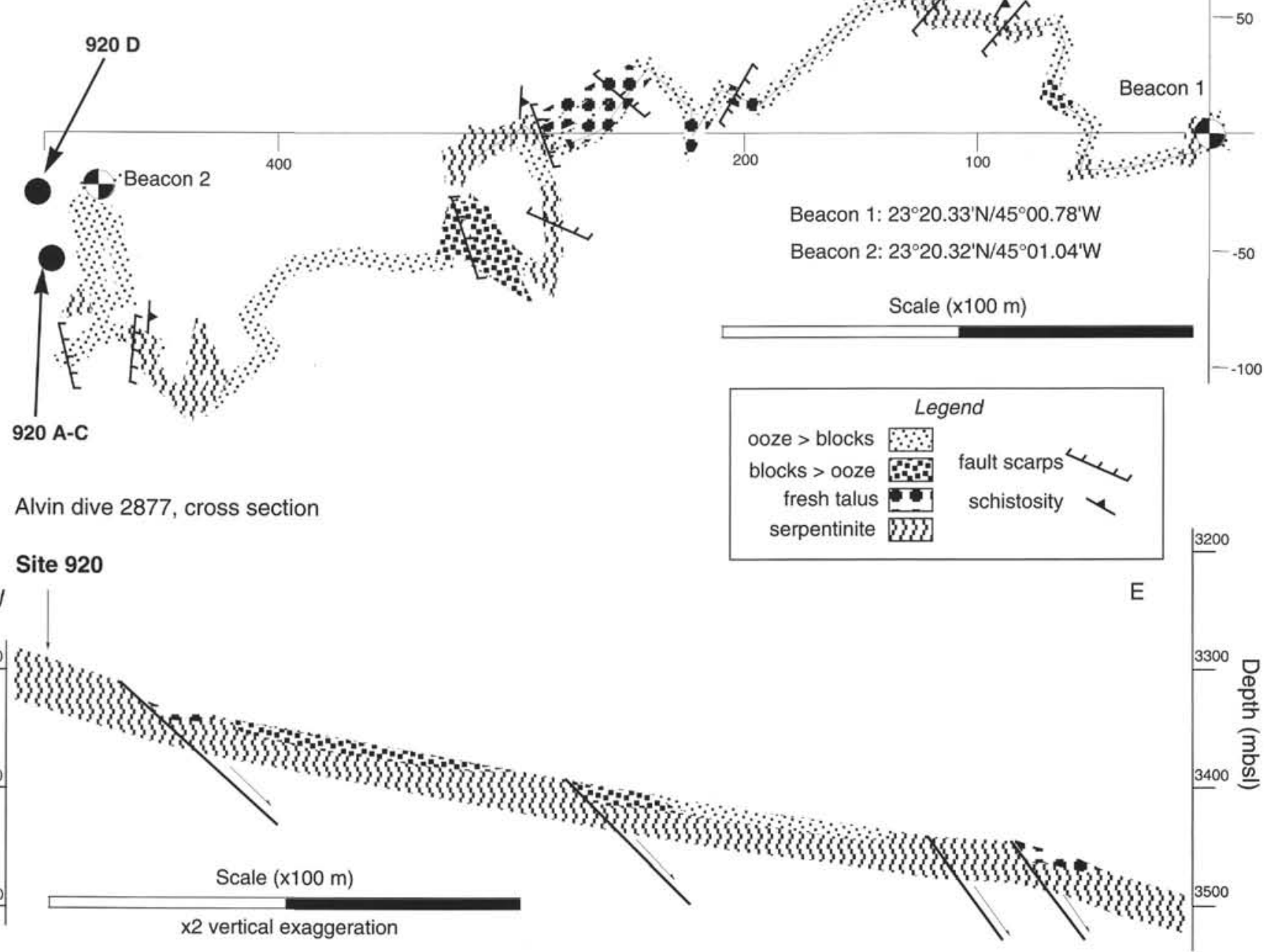

Figure 4. A. Summary of geology around Site 920 from an ODP video camera (VIT) survey conducted during Leg 153 (see Fig. 3 for location and symbols). Two fault scarps, each about $50 \mathrm{~m}$ high, occur along the camera track at $\sim 275$ and $\sim 475 \mathrm{~m}$ west of Beacon 1 . A number of smaller scarps, $<10 \mathrm{~m}$ high, are also mapped. Site 920 is located at Beacon 2 on a gently sloping outcrop surface above one of the major scarps. B. Cross section of the terrain and surface geology from Alvin dive 2877, which crossed Site 920 from east to west.

wide. The crest of the median valley wall is smooth and rounded and gives way to the west to a steep series of west-facing fault-line scarps (Figs. 2-4). No well-defined median valley wall is present in the vicinity of Site 670 and the serpentinites lie in the rugged bathymetric low of the segment boundary zone.

\section{Median Valley Floor}

Submersible dives and ANGUS camera tows confirm that the hummocky terrain of the side-scan sonar images corresponds to basaltic lavas of the median valley floor (Fig. 3). The lavas of this area have a moderate sediment cover ( $a$ few tens of centimeters thick) and appear to be substantially older than those of the neovolcanic ridge just to the east (Fig. 5A; Karson et al., 1987; Gente et al., 1991). The terrain is rolling, with hills and depressions on the order of 1-2 km across and 100-200 $\mathrm{m}$ high. Complex lava flow directions and flow fronts suggest multiple lava sources from various types of vents. Faults and fissures are not widely developed, as suggested by a lack of linear reflectors in the side-scan data. The western edge of the basaltic terrain of the median valley floor appears to lie between 3600 and $3500 \mathrm{~m}$ water depth and to deepen to the north.
Near Site 670 , the median valley floor of the segment boundary zone consists of faulted and fissured basaltic pillow lavas with a moderate to heavy cover of pelagic ooze. Faults, fissures, and sonar lineaments trend northwest, oblique to the spreading direction (Brown and Karson, 1988; Kong et al., 1988).

\section{Median Valley Wall}

The steep terrain with the lineated backscatter pattern of the western median valley wall was examined on Alvin (1684 and 2877) and Nautile (HS 13 and 19) dives. This is a region of active faulting and mass wasting dominated by extensive areas of carbonate ooze, rubble, intermittent large (up to a few meters across) boulders, and rugged outcrops (Figs. 3, 4). The lower slopes of this faulted region are dominated by extensive debris slide deposits. Upslope, the deposits are found to be fed by numerous slump scars that narrow downslope into V-shaped gullies and chutes. The angular shapes of the slumps and scoured debris-slide paths, as well as the lack of pelagic sediment over the mixed rock debris and sediment, indicate that these are active features. Clasts of both basaltic material and serpentinite have been collected from talus and debris slide deposits. 
A

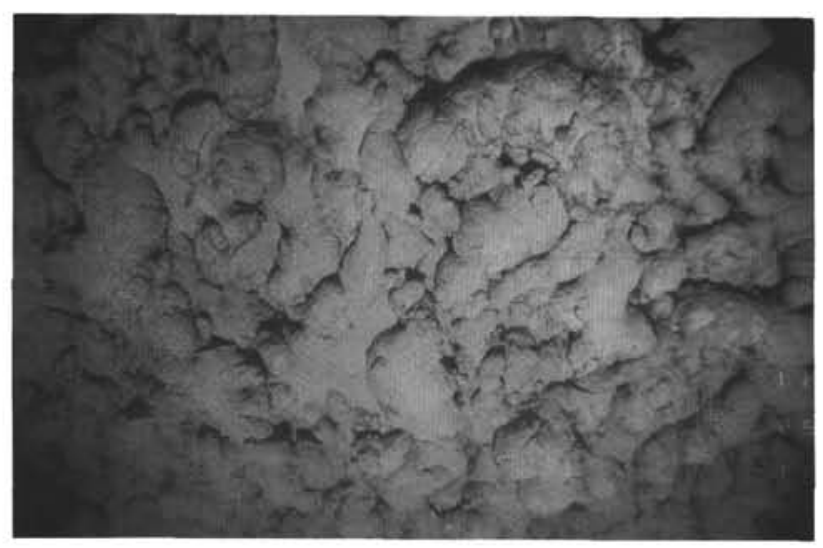

C

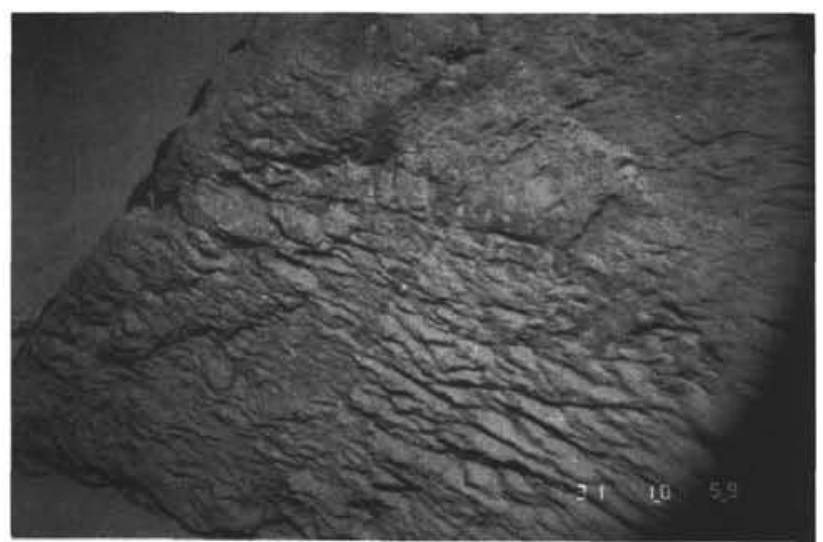

B

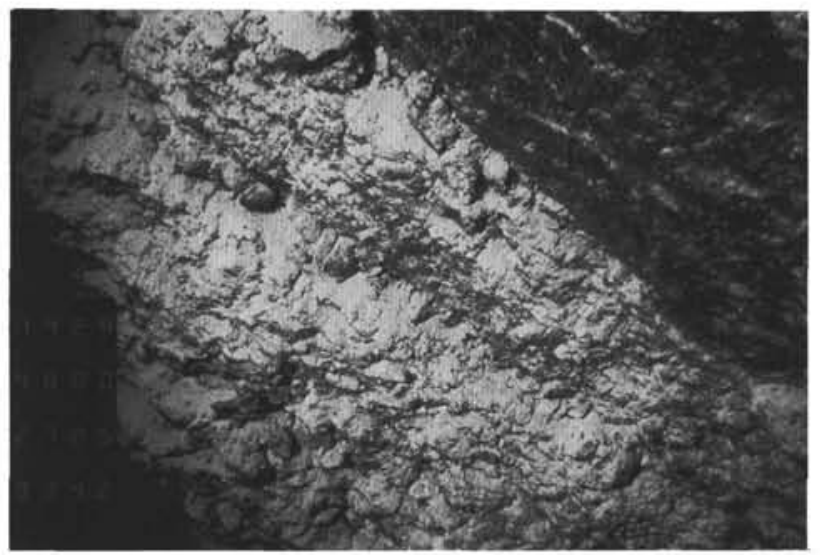

D

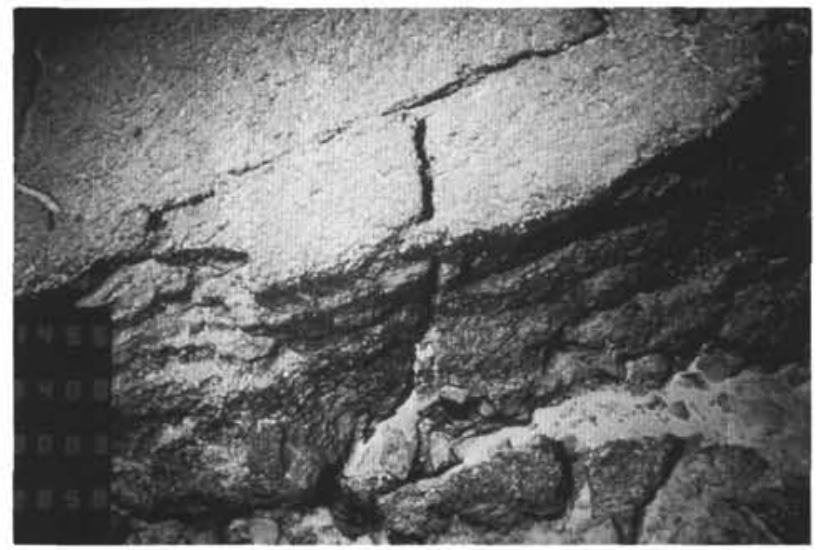

Figure 5. Outcrop photographs from the area surrounding Site 920 (see Fig. 3 for locations). A. Pillow lavas of the median valley floor just east of the serpentinite exposures; vertical-incident photograph from ANGUS run 4. B. Massive to phacoidal serpentinite with typical lumpy surface texture and east-dipping fabric; Nautile dive 13, depth $3342 \mathrm{~m}$. C. East-dipping schistosity in serpentinite outcrop; Alvin dive 2877, depth $3579 \mathrm{~m}$. D. Massive basaltic lava flow with subhorizontal base; Nautile dive 19, depth $2858 \mathrm{~m}$.

Steeper slopes are created upslope to the west by active faults with steep scarps of tens of meters to as much as $200 \mathrm{~m}$. These cliffs are rugged and angular, and commonly have fresh, sediment-free talus accumulations at their bases. They include mainly steep $\left(>60^{\circ}\right)$ fault scarps that strike about $010^{\circ}$, but also east-west jogs several meters in length that may be minor transfer faults or mass-wasting scars. The scarps expose large cross sections of massive to foliated serpentinite as well as overlying surficial deposits.

The serpentinites appear to have a crude, gently east-dipping, planar structure (Fig. 6A) defined by roughly tabular masses of serpentinite, typically less than one to several meters thick, with different internal fabrics (Karson et al., 1987; Mével et al., 1991). Some tabular units are massive, blocky serpentinite (Fig. 5B) with vertical joints spaced at several tens of centimeters. Commonly, the massive intervals grade into serpentinites with a well-developed, disjunctive, anastomosing foliation that also dips gently to the east (Fig. 5C). Others have more widely spaced anastomosing shear zones or schistose bands enclosing massive-looking phacoids of serpentinite. Submersible measurements of foliations also show gently to steeply dipping serpentinite shear zones interpreted as minor transfer structures and steep, east-northeast-dipping faults zones (Fig. 6A).

Alvin dive 1682 and Nautile dive HS-12 crossed extensive exposures of massive to schistose material but collected no serpentinite samples. It is not clear if these outcrops are some other rock type or
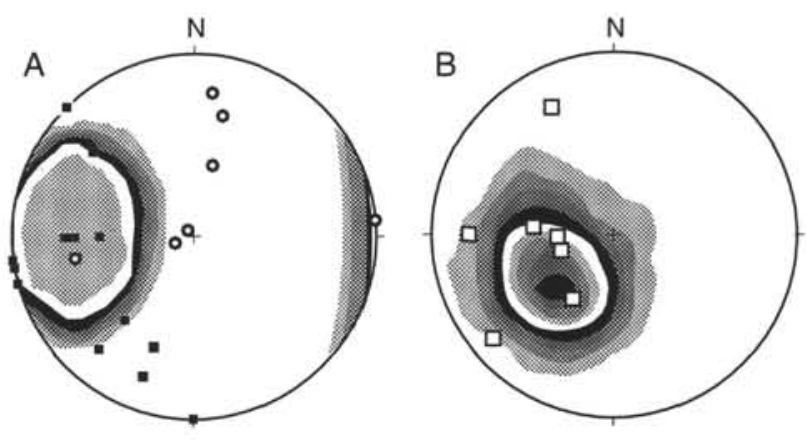

Figure 6. Structural data from submersible dives and Site 920. A. Kamb contour plot of foliations estimated from Alvin and Nautile dives; $\mathrm{n}=32$. Solid squares are foliations measured using the Geocompass on Alvin dive 2877. Open circles are seven steep fault zones estimated from Alvin and Nautile. B. Kamb contour plot of poles to anastomosing foliation measured in Holes $920 \mathrm{~B}$ and $920 \mathrm{D} ; \mathrm{n}=118$. Open squares are seven fault zones measured in the cores (data from Cannat, Karson, Miller, et al., 1995). $\mathrm{N}$ corresponds to $180^{\circ}$ of the core reference frame and is only approximately north (Hurst et al., this volume). Lower hemisphere stereoplots; contour interval is $2 \sigma$. 
A

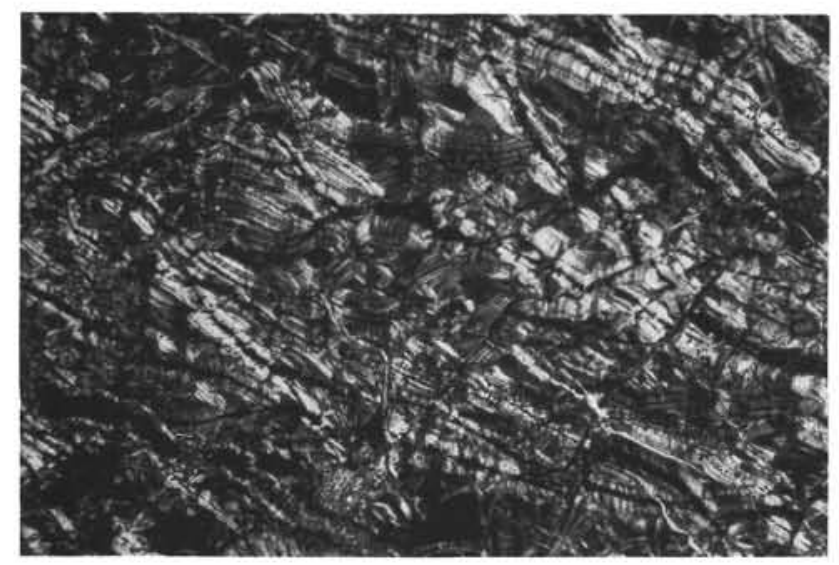

C

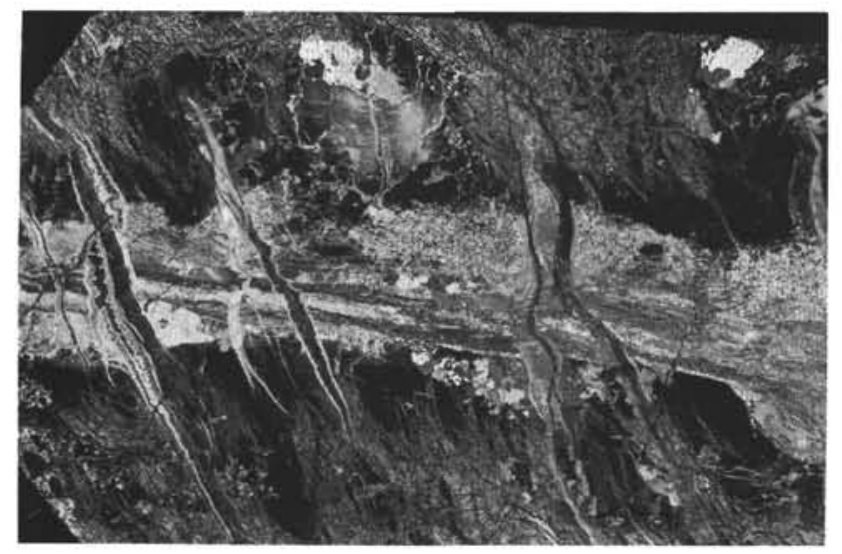

B

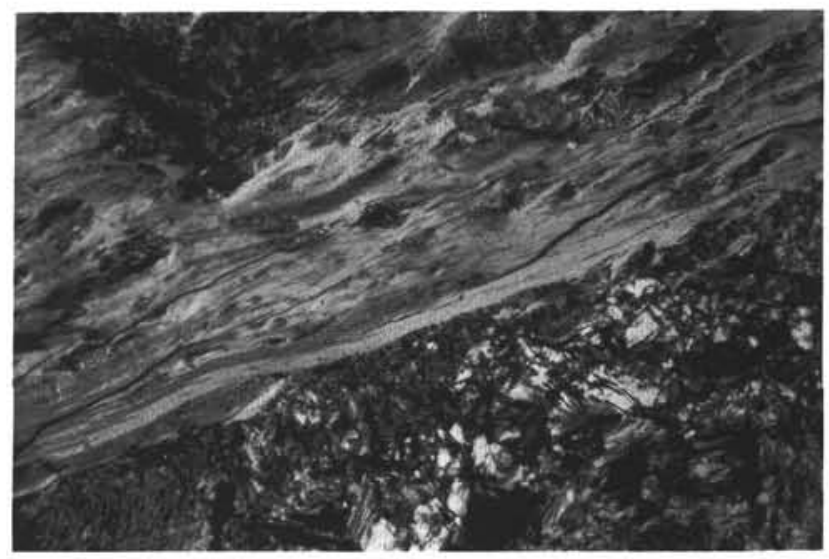

D

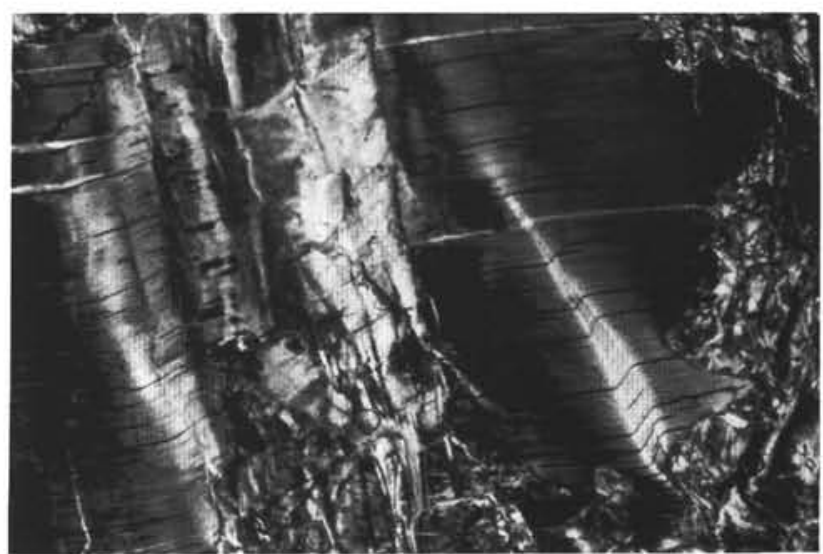

Figure 7. Photomicrographs of serpentinites near Site 920. A. Typical mesh-textured serpentine replacing peridotite; Sample 153-920D-16R-3 (Piece 1B, 2-4 $\mathrm{cm}$ ). B. Schistose serpentinite shear zone cutting mesh serpentine. Note the fine lamination and asymmetrical porphyroclasts; Sample 153-920B-10R-2 (Piece 5, 5-8 cm). C. Serpentinite shear zone cutting mesh serpentine and deformed bastites. Sigmoidal serpentine tension gashes with slightly curved serpentine cross fibers cut the shear zone; the earliest of the veins appears to be slightly deformed in the shear zone; Sample 153-920D-16R-3 (Piece 1B, 0-2 cm). D. Kinked bastite (serpentine after orthopyroxene) in mesh serpentine cut by spaced serpentine shear zones; Sample 153-920B-10R-2 (Piece 5, 3-4 cm). Long dimension of field of view is $4 \mathrm{~mm}$ for $\mathrm{A}-\mathrm{C}$, and $20 \mathrm{~mm}$ for D.

if sampling was simply inadequate to characterize them accurately. Several dredges in the area (Fig. 3), however, recovered abundant serpentinites and basalts (Gente et al., 1989).

Samples collected using Alvin and Nautile include massive to schistose serpentinized harzburgites (Fig. 7) cut by numerous veins of serpentine, carbonate, and clay minerals (Karson et al., 1987; Mével et al., 1991; J.A. Karson, S.D. Hurst, R.M. Lawrence, and SMARK Cruise Participants, unpubl. data, 1995). The low-temperature serpentine fabrics have an anastomosing aspect in hand specimen with phacoids of less-altered serpentinized peridotite separated by more schistose bands. The less altered domains are composed of peridotite with a coarse-grained porphyroclastic texture produced by high-temperature solid-state flow in the mantle. Coarse, elongated porphyroclasts of orthopyroxene (now bastites) are surrounded by aggregates of dynamically recrystallized olivine and pyroxene. Serpentinite fabrics more or less parallel the earlier high-temperature fabric, but numerous dilational veins cut both of these (Mével et al., 1991). Locally, the veins are deformed and contain kinked serpentine or synkinematic fibers.

Minor, variably altered veins occur in some samples. Surviving igneous mineralogies suggest a range from trondhjemite to oxide gabbro. Some veins show evidence of deformation and recrystalliza- tion under amphibolite to greenschist facies conditions (Mével et al., 1991; Tartarotti et al., 1995).

Locally, the steep fault scarps truncate an earlier family of gently east-dipping $\left(\sim 20^{\circ}-30^{\circ}\right)$ fault surfaces with down-dip grooves, striae, and slickenlines. The asymmetrical, stepped morphology of these relatively early fault surfaces suggests normal, down-dip displacement. It is not clear if these are major detachment surfaces or simply foliation surfaces exposed by spalling off of overlying slabs of serpentinite.

Surficial deposits found at the top of some steep fault scarps reveal some interesting aspects of the geologic history of the serpentinites. The most complete section of this material was found at a scarp during Nautile dive HS-13 (Fig. 8). Here, schistose serpentinites are directly overlain by a coarse, clast-supported breccia of angular cobbles of variably foliated serpentinite in a matrix of consolidated carbonate. The textural characteristics of this breccia suggest that it is an indurated talus or debris slide deposit. The breccia is overlain by a layer of semiconsolidated carbonate to friable chalk up to a few tens of centimeters thick. These deposits are poorly laminated and extensively burrowed. They are stained dark brown along their undulating lower contact against the breccias. The chalks are overlain by several centimeters of very poorly consolidated carbonate ooze. 


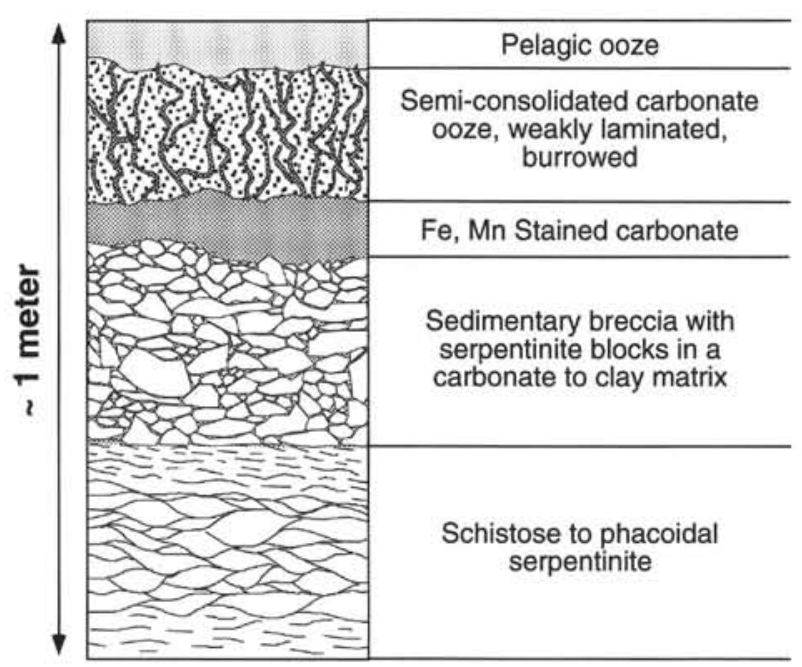

Figure 8. Highly generalized columnar section of rock units exposed in a steep, young, fault scarp in the serpentinite exposures seen on Nautile dive HS-13 (J.A. Karson, observer).

The breccias, chalks, and underlying serpentinites are cut by numerous small faults and fractures that appear to have produced gentle undulations in the sedimentary cover. These deposits suggest that serpentinite surfaces, like the low-angle faults described above, have been exposed for significant periods of time on the seafloor (Fig. 9).

\section{Crest of the Median Valley Wall}

The crest of the median valley wall lies at a depth of about 3100 $\mathrm{m}$. It is a rounded shoulder with basaltic outcrops and rubble exposures protruding from an extensive blanket of pelagic ooze. The rubble exposures occur as low ( $<1 \mathrm{~m}$ high) elongate ridges of intensely fractured but strongly welded basaltic material. The ridges tend to be oriented parallel to the active faults of the median valley wall $\left(010^{\circ}\right)$ and produce strong, linear backscatter reflections on submersible scanning sonar systems. Rarely, minor fault scarps expose the upper lip of a faulted block of truncated basalt pillows and/or flows (Fig. 5D). Samples collected here are fractured, weathered, and veined, but they are relatively fresh compared with other basaltic rocks collected at distances greater than $10 \mathrm{~km}$ from the Mid-Atlantic Ridge axis that are inferred to be $>1$ m.y. old. Near Site 670, Alvin dive 1689 encountered intact sheet flows upslope from the serpentinite exposures. The contact between these units was not observed. The basalts have only 1-2 $\mathrm{m}$ of sediment cover, in contrast to the $12 \mathrm{~m}$ reported from drilling at Site 670 (Detrick, Honnorez, Bryan, Juteau, et al., 1988), suggesting a significant age difference between these sites. The sediment thicknesses, however, may have been altered by current action or slumping. If significant, the thickness variations suggest that the basalts in this area may have been erupted sometime after the exposure of the serpentinites. West of Site 920, Nautile dives (HS-19 and 20) surveyed extensive exposures of basaltic lavas truncated and exposed by west-facing faults. No serpentinites have been found on the western slopes beyond the crest of the median valley wall. The contact between the serpentinites and lavas has not been seen in outcrop and appears to be generally obscured by mass wasting and pelagic sedimentation.

\section{CORRELATION OF OUTCROP AND DRILL HOLE GEOLOGY}

Drilling on Leg 153 has provided new and important constraints on the nature of the serpentinite exposures in the MARK area (Can-
A

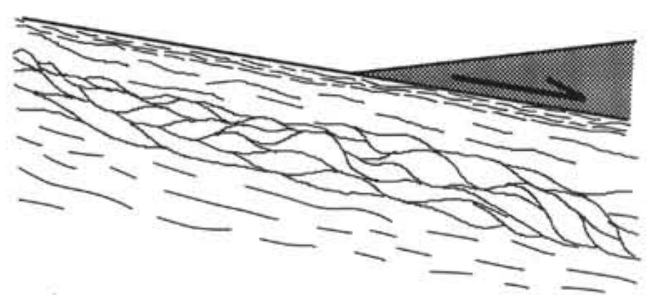

B

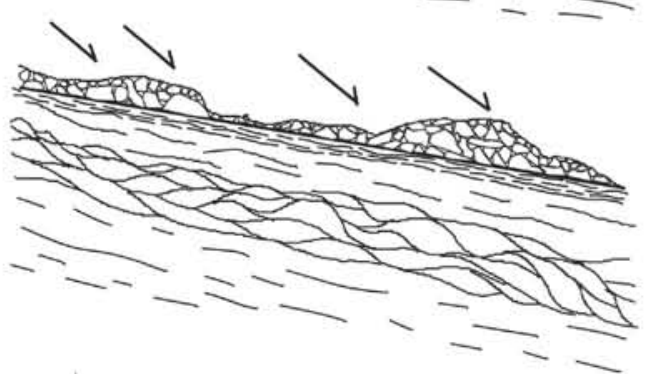

C

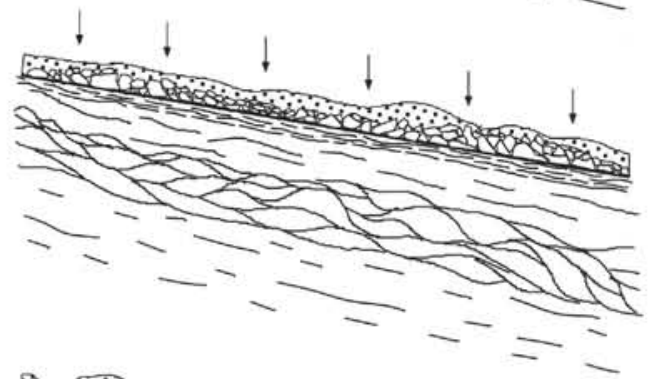

D

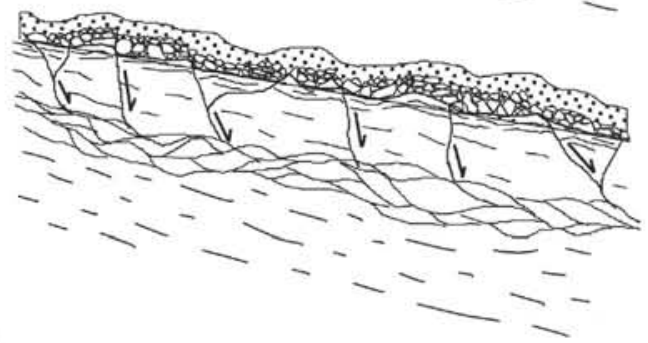

E

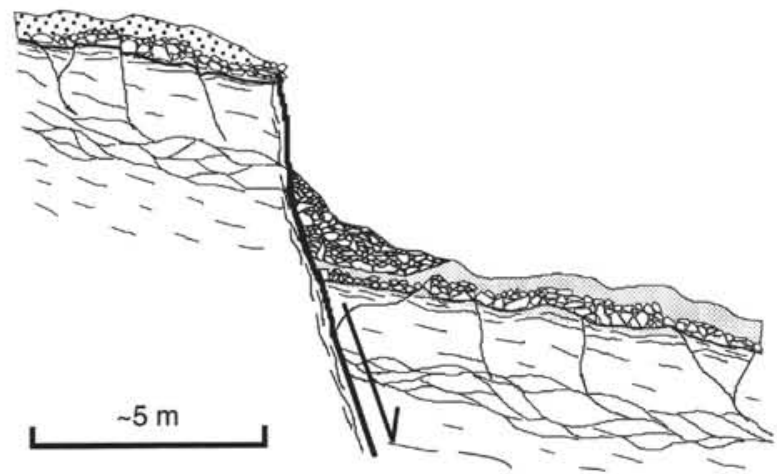

Figure 9. Sketches suggesting the inferred post-serpentinization evolution of the serpentinite massive near Site 920. A. Heterogeneous deformation of the serpentinites to produce a domainal fabric with discrete units of serpentinite ranging from tabular, massive, veined units with a blocky aspect to strongly schistose intervals with planar to phacoidal outcrop-scale fabrics. B. Deposition of coarse, poorly sorted, angular blocks of schistose to massive serpentinite by mass wasting. This material became indurated as a clast-supported breccia. C. Deposition of pelagic carbonate ooze that consolidated to produce an extensively burrowed, poorly laminated, chalky deposit. D. Warping and minor normal faulting. E. Normal faulting with vertical separations of up to several tens of meters. Fresh talus deposits accumulate at the base of the scarps. 
nat, Karson, Miller, et al., 1995). Here we provide a brief summary of these results and discuss them in terms of the outcrop data presented above. We emphasize features that bear on the regional geology of the MARK area and the mode of uplift and exposure of the serpentinites.

Examination of the drill cores from Site 920 has provided detailed information on the serpentinite body down to depths of $200 \mathrm{~m}$. In general, the lithologic variations, types of fabrics, and other features observed are very similar to those noted in outcrops. Drilling showed that serpentinites, similar to those of the submersible samples, persist to the maximum depth penetrated $(200 \mathrm{~m})$. The alternating tabular layers of serpentinite with different mesoscopic fabrics observed in outcrops are manifest in the drill cores as variations in modal pyroxene and variations in the intensity of the porphyroclastic fabric, schistosity, and vein development. Alternating bands of variable modal pyroxene content ranging from dunite to harzburgite to rare pyroxenite were found in cores from both Holes 920B and 920D (Fig. 10). Numerous highly altered mafic mineral segregations are interpreted as the traces of melt channels. These include mineral trails the width of a single grain as well as veins and small dikes a few centimeters in width. The segregations are variably deformed under amphibolite to greenschist facies conditions, but have no strong preferred orientation.

In addition to the lithologic variations, several structural domains defined on the basis of smoothly varying or homogeneous fabrics were identified (Fig. 10). The internal structure of each domains reflects a limited range of intensity and/or relative orientation of one or more of the individual mesoscopic fabrics observed in the cores. Several domain boundaries coincide with those of the major lithologic units, reflecting the strong influence of modal mineralogy on fabric development. Domain boundaries also occur within the serpentinite units on the basis of changes in the mesoscopic fabrics. Most of these are placed between core sections actually recovered and, therefore, the exact nature of these contacts is not known.

The dominant textural type is harzburgite with a gently to moderately dipping foliation defined by the elongation of orthopyroxene

\section{A Hole 920B}

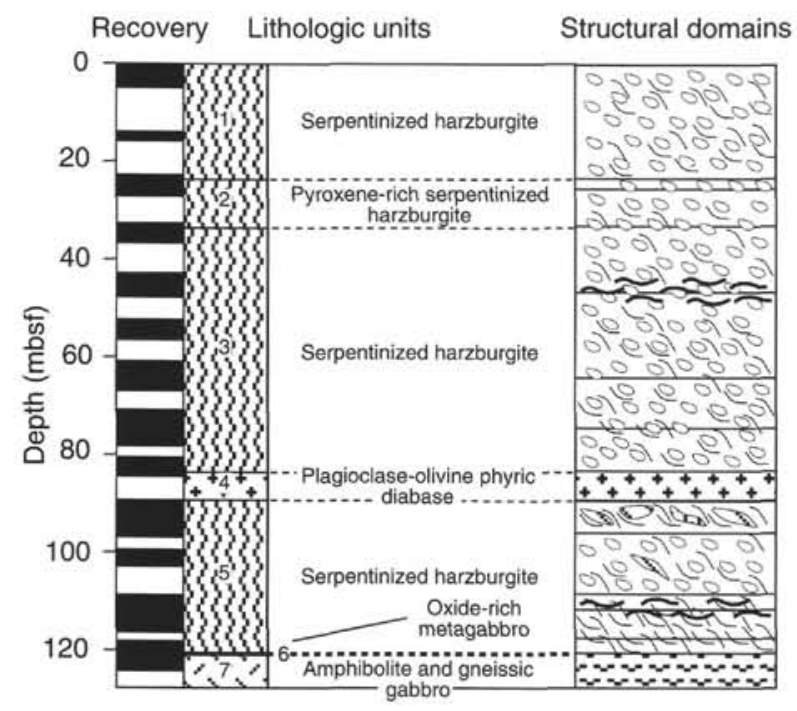

Total depth $126.4 \mathrm{~m}, 39.7 \%$ recovery

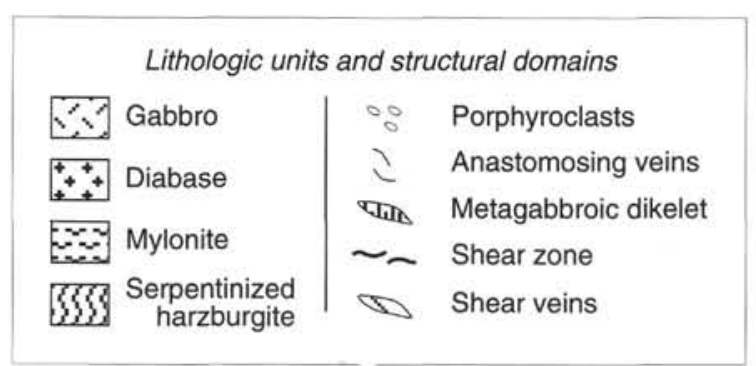

B Hole 920D

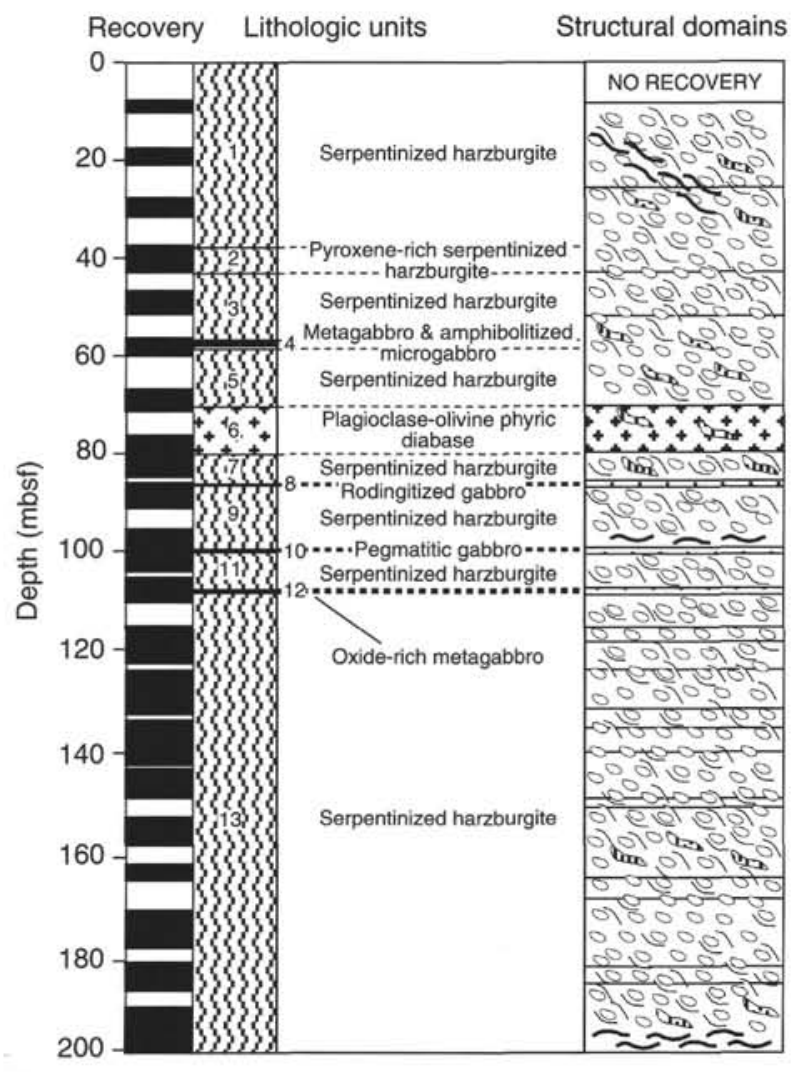

Total depth $200.8 \mathrm{~m}, 47 \%$ recovery

Figure 10. Core recovery (in black) for Holes 920B (A) and 920D (B) showing the distribution of lithologic units and structural domains. The recovery is plotted as the cumulative section length shown as if it were continuous from the top of each core. The majority of the core is serpentinized harzburgite with varying modal abundances of pyroxene. The serpentinized harzburgite units are separated by discrete gabbro, metagabbro, and diabase units. The qualitative structural domains indicated are defined by the visual description of the orientations, intensities, and relationships among various mesoscopic fabric elements observed in $\therefore$,e cut face of the core. The structural domain boundaries generally coincide with lithologic unit boundaries, although some are placed within the serpentinized harzburgite units. In most cases, the boundaries have not been directly observed because they fall between core pieces (compiled from Cannat, Karson, Miller, at al., 1995). In general, the structural domain orientations are not known and are not necessarily horizontal as shown. Note that all symbols are schematic and are meant to summarize general mesoscopic structural associations rather than individual features. 
A

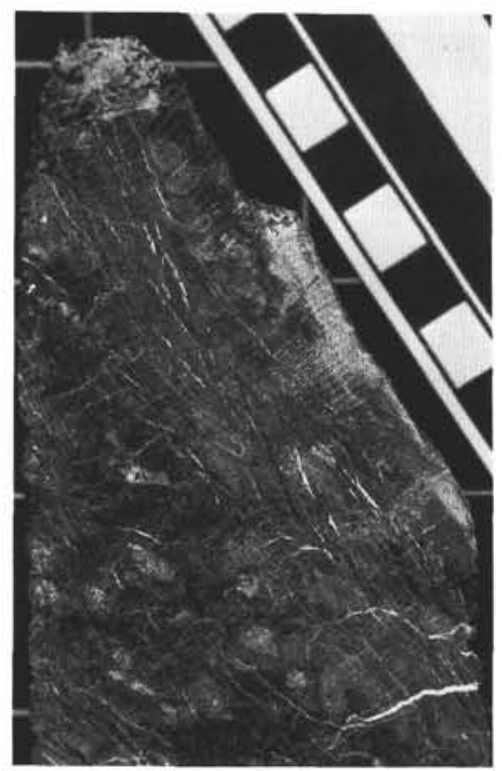

C

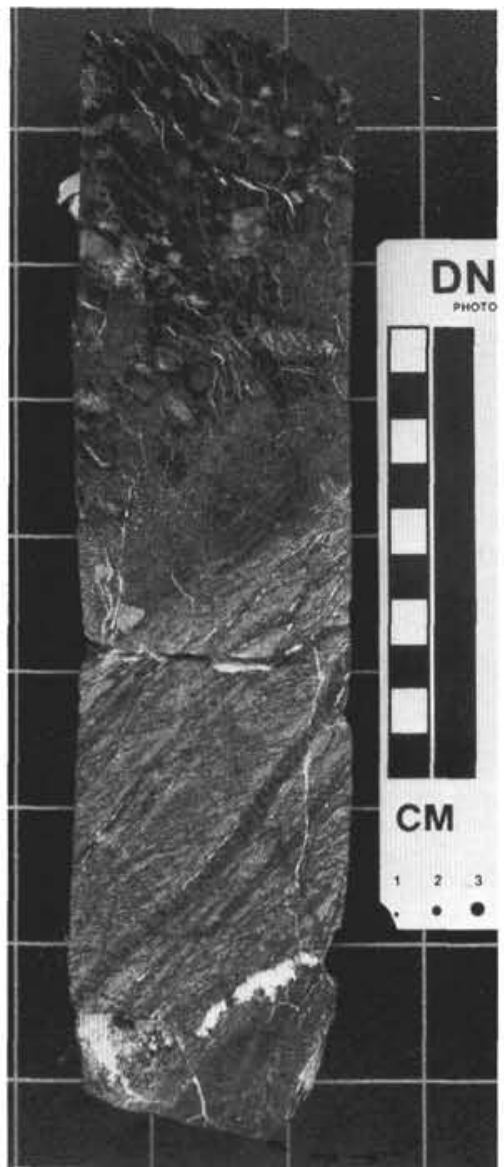

B

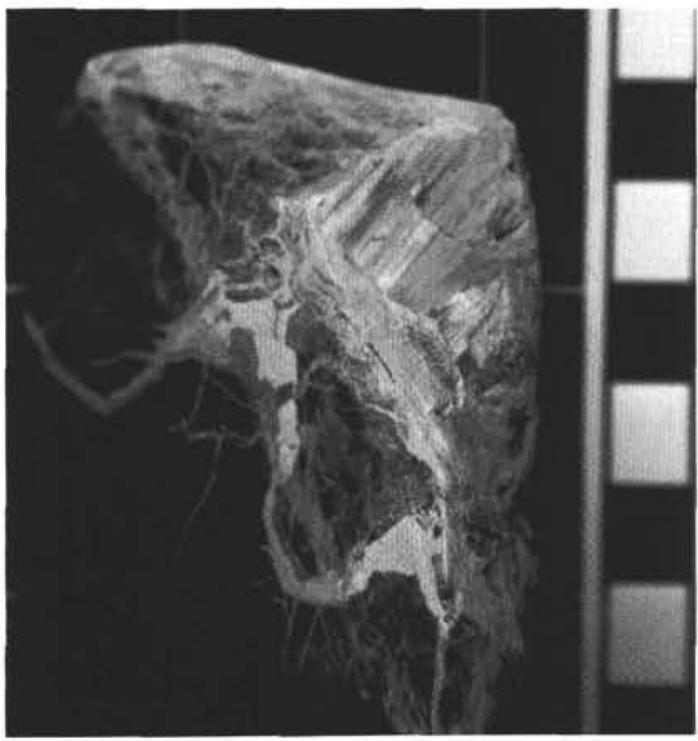

D

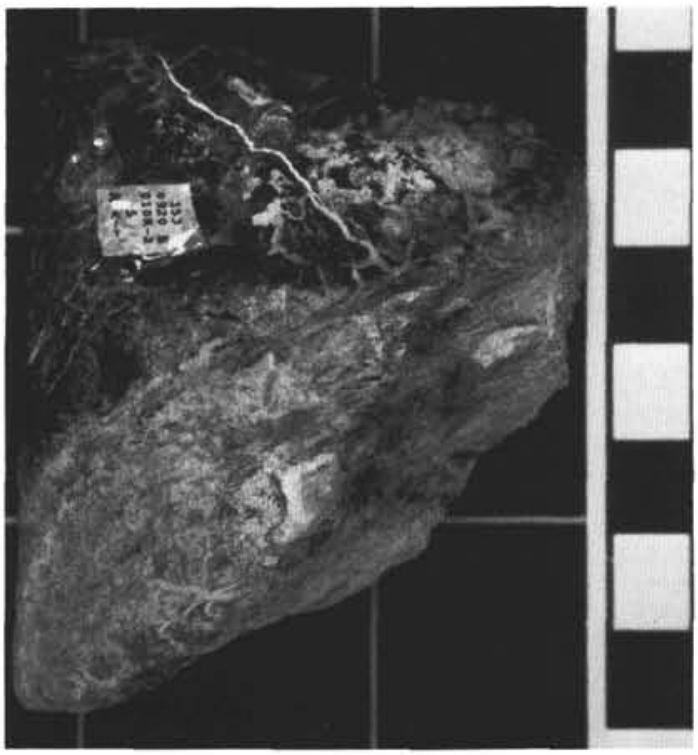

Figure 11. Core photographs from Site 920. A. Porphyroclastic serpentinized harzburgite grades upward into increasingly densely veined and sheared serpentinite. Inclined surface is covered with a mat of greenish white serpentine fibers; Sample 153-920B-10R-2 (Piece 2, 0-12 cm). B. Close-up photograph of serpentine slickenfibers on piece shown in A. C. Inclined serpentine shear zone almost completely replaced by anastomosing dilational serpentine veins; Sample 153-920D-12R-2 (Piece 6, 0-24 cm). D. Slickenlines on bottom of inclined fault zone in serpentinite; Sample 153-920B-10R-2 (Piece 5). Centimeter scale shown on all photographs. 
porphyroclasts. Despite the relatively consistent orientation of this mesoscopic porphyroclastic fabric, microscopic spinel shape foliation and lattice preferred orientations of olivine and orthopyroxene show significant downhole variations in strength and orientation (Ceuleneer and Cannat, this volume). An overprinting anastomosing serpentinite fabric (Dilek, Coulton, et al., this volume) is commonly subparallel to the mesoscopic porphyroclastic fabric. This relatively low-temperature fabric is dominantly dilational, and shearing displacements parallel to these surfaces are rare. Several other families of serpentine veins with little or no preferred orientation are also well developed (Dilek, Coulton, et al., this volume).

The mesoscopic and microscopic foliations, structural domain boundaries, and major lithologic contacts are all generally parallel. The earliest, high-temperature spinel, olivine, and orthopyroxene fabrics appears to have a more variable orientation. Paleomagnetic constraints indicate that the dominant mesoscopic fabrics dip to the east-northeast (Fig. 6B; Hurst et al., this volume). The composite fabric defined by these elements clearly correlates with the mesoscopic foliations observed from submersibles.

At Site 920 serpentinite shear zones that could correlate with discrete low-angle fault surfaces observed from submersibles were only rarely recovered (Cannat, Karson, Miller, et al., 1995). Most of the serpentine in the cores appears to have grown under static conditions resulting in volumetric expansion Serpentine minerals in mesh-textured overgrowths and veins are commonly not strained; however, sheared, schistose serpentinite samples were found at the edges of many core pieces (Fig. 11). These commonly occur above and/or below core intervals that separate compositionally or texturally different rock types. These intervals are as much as a few meters wide and are inferred to be areas of rubbly or highly fractured rock where recovery was very low or nil. Slickensided surfaces are common and vein densities and the overall degree of serpentinization tend to increase adjacent to these intervals (Fig. 11). It has long been suspected that fault zones are undersampled by ODP drilling, and we suspect that the missing intervals correspond to fault zones in the serpentinite that are difficult to recover with rotary drilling techniques.

The drill core reveals that gabbroic intrusions are much more common and have a wider range of compositions than suggested from the surface samples. These include trondhjemite, oxide gabbro, gabbro, olivine gabbro, and gabbronorite (Fig. 10). They cut earlier high-temperature peridotite fabrics and have been variably deformed under low-pressure granulite to amphibolite to greenschist facies conditions and have fabrics ranging from well-preserved igneous textures to mylonites. The latest of these intrusions are sparsely plagioclase-phyric diabase dikes with well-developed chilled margins. Very little gabbroic material was recovered from surface exposures and no dikes were observed in the outcrops. Overall, the mafic intrusive material suggests a protracted history of minor injections of variable, but commonly highly evolved, igneous material. Post-intrusion deformation and incomplete core recovery precludes any accurate estimate of the thickness of many of these bodies, but the total volume recovered is less than $5 \%$ of the core.

\section{DISCUSSION Surface Studies and Drilling-Complementary
Approaches}

Faulted exposures of coarse-grained gabbroic rocks and serpentinized peridotites on the median valley walls provide important "tectonic windows" into lower crustal and upper mantle rock units of the oceanic crust. Drilling into areas that have been studied in detail at the surface has provided constraints on the vertical dimensions of rock masses and made it possible for the first time to begin to appreciate the internal structure and composition of major volumes of oceanic crust. On the slow-spreading ( $20 \mathrm{~mm} / \mathrm{yr})$ Mid-Atlantic Ridge, the first drilling of such tectonic windows has provided new insights into the creation and modification of oceanic crust in this environment.

From the brief comparison of surface studies and drilling results, it is clear that these two different approaches to studying the serpentinites of the MARK area are complementary rather than redundant. Data from these two perspectives overlap to some extent, but both approaches provide unique types of information.

Seafloor studies at different scales of resolution help map out the extent of surface exposures and surface structures. Sampling is difficult and subject to biases imposed by the best exposures occurring on young fault scarps. Lithologic contacts are commonly covered by pelagic sediment or mass-wasting deposits and are only rarely observed in outcrops. Both steep and gently dipping fault zones are best studied from submersibles, at least in rock types like serpentinites. Drilling provides only a one-dimensional sample of rock masses, but it provides a relatively complete vertical section. The maximum size samples from submersibles are only a few tens of centimeters in length; whereas drilling at Site 920 provided samples from a vertical interval of $200 \mathrm{~m}$ with approximately $40 \%$ recovery. Even with uncertainties of a few meters in the exact position of core pieces within a given section, this type of sampling cannot be accomplished using submersibles along steep scarps. In any case, few steep fault scarps reach this vertical dimension, and they are almost always complicated by numerous secondary fractures and joints and accumulations of loose debris. Individual fault scarps are typically limited to a few tens of meters and pre-existing fabrics are subject to overprinting by the faults that expose them.

Together, surface studies and drilling have provided a unique view of the internal architecture of the serpentinite body on the western median valley wall of the MARK area that would not be possible from either approach alone. This dual approach provides new insights into the evolution of peridotites beneath the spreading axis, the mechanisms by which serpentinites are exposed at the seafloor, and the post-serpentinization history of this terrain. The inferences possible from this area have important implications for seafloor spreading at slow-spreading rates and/or very low magma budgets worldwide.

\section{Subaxial History}

The subaxial mantle history of the peridotites drilled at Sites 670 and 920 are reported in detail elsewhere (Juteau, Berger, et al., 1990; Komor et al., 1990; Cannat, Karson, Miller, et al., 1995) and in this volume. In brief, the fabrics in the peridotites suggest solid-state flow under high-temperature, low strain rate, and low deviatoric stress conditions, believed to have been present in the asthenosphere. Overprinting fabrics appear to have developed under conditions of higher stresses more likely to have been encountered in the lithosphere (Ceuleneer and Cannat, this volume). The high-temperature fabrics appear to be highly variable in their intensity and orientation; howev$\mathrm{er}$, the dominant lower temperature mesoscopic fabrics are consistent in their east-northeast-dipping orientation in both outcrops and in the drill holes.

Mineral segregations interpreted as material crystallized along melt channels record the synkinematic transport of partial melts through the deforming peridotites. The intercalated gabbroic masses are larger segregations of relatively highly evolved melts that intruded the peridotites (Cannat, Chatin, et al., this volume; Casey, this volume; Niida, this volume). Many of these were subsequently deformed and metamorphosed under high-temperature anhydrous (lowpressure granulite facies) to low-temperature hydrous conditions (greenschist facies and lower). Locally, the mesoscopic deformation fabrics in the gabbroic rocks appear to be parallel to the high-temperature fabrics of the peridotites but discontinuities in the cores make it difficult to determine if fabrics in the various units formed during the same events. 
Despite the relatively depleted nature of the mineral chemistry of the peridotites compared to other oceanic peridotites and ophiolites (Casey, this volume), they lack a substantial overlying magmatic crust. Melt derived from the peridotites may have been transported laterally along the ridge axis to other areas. Alternatively, a substantial thickness (few kilometers) of magmatic rocks may have once overlain the peridotites. These may have been tectonically removed by displacement on major crustal detachments that flattened near or beneath the top of the peridotites as discussed below.

\section{Uplift and Exposure of Upper Mantle Material}

Several different mechanisms have been suggested for the exposure of serpentinized upper mantle material along mid-ocean ridges. Below we consider the serpentinite exposures in the MARK area in light of these hypotheses.

\section{Serpentinite Diapirism}

Following workers in oceanic fracture zones (Bonatti, 1976), some investigators have suggested that serpentinites intrude the entire thickness of the crust as low-density diapirs (Aumento and Loubat, 1971; Bonatti and Hamlyn, 1981; Francis, 1981). It is believed that major rift-valley fault zones that penetrate the upper mantle permit the deep penetration of seawater and the local hydration of peridotites, lowering their density. The faults are also thought to provide conduits through which the serpentinites can flow upward into the crust.

Studies of serpentinite seamounts in the Mariana and Izu-Bonin forearcs suggest that serpentine muds are periodically extruded in a faulted serpentinite terrain (Fryer, 1992). The muds are thought to be composed of serpentinite fault gouge expelled under elevated fluid pressures. A variety of mafic and ultramafic clasts are entrained in a complexly deformed matrix. Fluids from the subjacent subducted slab are thought to mobilize this material. On the surface, the serpentinite muds are deposited as debris flows on the flanks of more massive serpentinite horsts (Fryer, 1992). Whereas vertical ascent of serpentinite muds is well established in this forearc environment, midocean ridge settings would lack the deep fluid source that could weaken and lower the density of serpentinites at depth.

There are two possible theoretical problems with low-temperature $\left(<500^{\circ} \mathrm{C}\right)$, solid-state serpentinite diapirism. First, the densities of oceanic serpentinites generally lie between 2.6 and $2.8 \mathrm{~g} / \mathrm{cm}^{3}$ (Christensen, 1992), not substantially different from typical oceanic gabbroic rocks, giving them a negligible buoyancy relative to likely surrounding crustal rocks. Second, serpentinites are commonly inferred to be very weak compared to mafic crystalline oceanic rocks. Experimental studies support this claim only to the extent that they show serpentinites to be very weak during active dehydration (Raleigh and Patterson, 1965) and that lizardite serpentine appears to have a relatively low coefficient of friction (Dengo and Logan, 1981; Reinen et al., 1991; Escartín et al., 1994). Confusion appears to stem from the ductile style of deformation of serpentinites in subaerial exposures such as ophiolites. The style of deformation, however, is not necessarily an indication of relative strength.

The MARK serpentinites are typically altered to $>80 \%$ serpentinite and are expected to have undergone significant volumetric expansion, probably 20\%-30\% (Coleman, 1971, O'Hanley, 1992). Despite the apparent lack of density and strength differences with typical oceanic crustal rocks, this volumetric change may be sufficient to drive serpentinites vertically through fault zones in an extensional environment.

Serpentinites in the MARK area generally lack the features that might be expected in serpentinite diapiric protrusions such as those of western Pacific forearcs (Fryer, 1992). Instead of being localized along narrow, steep fault zones or fault intersections, they appear to occupy a broad swath with irregular boundaries, suggesting low-angle contacts with surrounding rock units. They also lack steep, serpentinite deformation fabrics that would be acquired during vertical ascent; serpentinite fabrics dip consistently to the east or east-northeast at about $20^{\circ}-50^{\circ}$. Whereas gently dipping fabrics might be expected locally in the crest of a laterally spreading diapir, fabrics throughout the serpentine outcrops and in separate locations spanning $20 \mathrm{~km}$ along the Mid-Atlantic Ridge appear to be consistent. In addition, the MARK serpentinites lack the randomly oriented, exotic blocks and complexly deformed serpentinite mud matrix found in forearc diapirs. Serpentinite mud debris flows that might be sourced in such protrusions have not been found.

\section{Detachment Faulting}

Serpentinized upper mantle material could also be exposed on the seafloor by unroofing of any overlying magmatic crustal rocks by slip on major detachment faults (Fig. 12). Removal of upper crustal rocks on this scale occurs in the metamorphic core complexes of highly extended continental terrains (Wernicke and Burchfiel, 1982; Lister and Davis, 1989) and has been suggested for the unroofing of gabbroic rocks along slow-spreading ridges (Dick et al., 1981; Karson and Dick, 1983; Karson et al., 1987; Karson, 1990; Mutter and Karson, 1992; Tucholke and Lin, 1994). This interpretation would be in accord with the gently east-dipping fabrics of the serpentinites and the high strains recorded in the intercalated metabasites. Only a small number of small, low-angle, serpentinite fault zones were recovered in the drill cores, but extensive low-angle normal fault surfaces were observed from submersibles. Any previously overlying magmatic crustal rocks would now be allochthonous fragments displaced either to the east or west of the present serpentinite exposures depending upon the original dip and transport direction of the major faults.

Middle to lower crustal gabbroic rocks are exposed in a broad outcrop area just to the north of the serpentinite outcrops described in this paper. Diapirism is not a viable mechanism for the exposure of these deep-level mafic rocks, and major low-angle fault zones are well documented (Karson and Dick, 1983; Karson et al., 1987; Karson, 1990; Karson and Lawrence, this volume). If low-angle detachment faulting can expose even deep-level mafic rocks in a crustal section thought to be a few kilometers thick, a similar mechanism seems feasible to expose mantle peridotites just along strike in the same spreading segment. Even less extension and mechanical thinning than apparent in the gabbroic terrain to the north would be required if the MARK peridotites existed beneath a relatively thin crustal carapace.

Extensional thinning of an overlying magmatic crust would be possible, but much less efficiently accomplished, on steeply dipping normal faults. This would require domino-style block rotations and multiple generations of faults as seen in many continental extensional regimes (Wernicke and Burchfiel, 1982). With a crustal thickness of several kilometers, this would require a very large amounts of horizontal extension, probably over a very wide area. Moreover, significant tectonic rotations of fault blocks would be expected, and these have not been observed.

\section{Extension of Serpentinite Crust}

With prophetic vision, Hess (1962) suggested that a substantial portion of the oceanic crust might be composed of serpentinite, essentially upper mantle peridotites that were uplifted, faulted, and hydrated as they spread laterally at mid-ocean ridges. This concept has been reborn with the discovery of extensive serpentinite exposures along significant portions of the median valley walls of slow-spreading ridges. In some places, serpentinites occur on both sides of the median valley (Cannat, 1993; Cannat et al., 1995). It has been suggested that rising mantle material may develop only intermittent gab- 

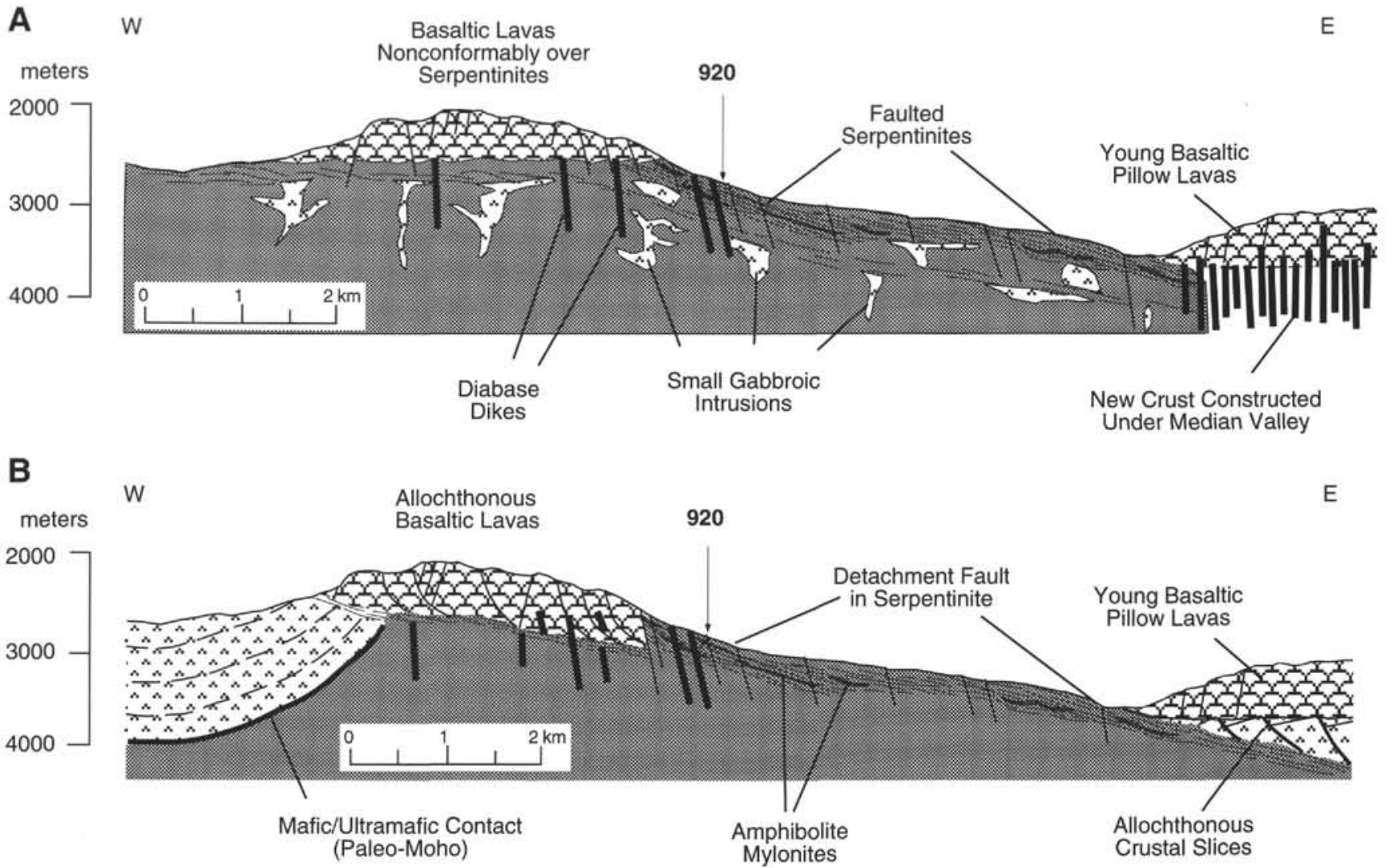

Figure 12. Generalized cross sections illustrating the possible geologic relations around Site 920 based on submersible and drilling results. A. The serpentinite exposure could be the result of seafloor spreading with a very low and intermittent magma supply and transport of altered upper mantle material to the shallow crust (Brown and Karson, 1988; Cannat, 1993; Cannat et al., 1995). Minor faulting could expose serpentinites and minor intrusions beneath a thin or discontinuous cap of basaltic lavas. Such exposures could be very continuous laterally along flow lines or asymmetric V-shaped ridges (Cannat et al., 1995) or are bracketed by crustal masses produced by magmatic construction. B. Serpentinite exposures could also be essentially the footwall of major detachment faults with discontinuous, overlying, allochthonous, hanging wall fragments of dismembered crust and/or autochthonous lava caps erupted onto the fault surface. It is also possible that the exposures are the result of some combination of the end-member effects shown in A and B.

broic intrusions and a thin or even discontinuous basaltic cap, rather than a thick, continuous magmatic crust as commonly inferred from seismic studies and ophiolite complexes (Brown and Karson, 1988; Cannat, 1993).

Deformation fabrics, minor intrusions, and local geology could all be in accord with this model as well (Fig. 12). Substantial faulting would be expected in serpentinites exposed from such spreading mantle material and this could include major low-angle or high-angle normal faulting, or some combination of the two. Studies of crustal rocks to the east and west of the serpentinite exposures in the MARK area will be required to determine if a magmatic upper crust has been tectonically removed from this terrain.

\section{Post-Serpentinization History}

Following serpentinization and uplift of the serpentinized peridotites, local geological relationships give some clues to the recent history of this area (Fig. 9). First, the surficial deposits described previously suggest that the serpentinites were exposed at the seafloor for a substantial period of time. Deposition of serpentinite breccias may have accompanied low-angle normal faulting or a later deformation. Neglecting any compaction and diagenesis, and considering only estimated Mid-Atlantic Ridge sedimentation rates (Marks, 1981), the $\sim 20 \mathrm{~cm}$ of pelagic sediment probably represents at least $10,000-$ $20,000 \mathrm{yr}$ of accumulation.

The sedimentary cover of the serpentinites is overlain by fresh talus from faults created as the serpentinites spread laterally into the median valley wall. Thus, the serpentinites appear to have been exposed on the floor of the median valley for some time, perhaps tens of thousands of years. The basaltic lavas of the neovolcanic ridge and adjacent median valley floor just to the east may have been erupted directly on to the exposed serpentinite terrain. This results in geologic relations commonly found in some Alpine and Apennine ophiolites (Barret and Spooner, 1977; DeLong et al., 1977; Cortosogno et al., 1978; Abbate et al., 1980; Lemoine et al., 1987; Pinet et al., 1989; Lagabrielle and Cannat, 1990). Although many of these ophiolites have been interpreted in terms of transform faults, similar geological relations have been documented in the serpentinite bodies in the MARK area and elsewhere on the Mid-Atlantic Ridge and may therefore represent various manifestations of slow-spread crust (Lagabrielle and Cannat, 1990; Karson, 1990).

The contact between the lavas that crop out on the crest of the median valley wall above Sites 670 and 920 has not been directly observed, however, a number of observations suggest that they were erupted directly over the serpentinites. This might have occurred in the median valley floor or at off-axis eruptive sites. First, the basalts, although locally intensely fractured, are largely intact. Even rather fragile sheet flows observed during Alvin dive 1689 just above Site 670 are essentially undisturbed. Second, although not definitive, the sediment cover on the lavas is substantially less than that on the nearby serpentinites on the same slope, suggesting that the lavas are somewhat younger. Finally, the essentially undeformed diabase dikes recovered from cores at Site 920 cut the serpentinite fabrics. Similar dikes could be the feeders for post-serpentinization lava flows. At 
present, no detailed comparison between the geochemistry of these dikes and the nearby lavas has been made.

The latest event affecting the serpentinite area is normal faulting associated with the creation of a poorly developed median valley wall. Although poorly understood, such faulting marks the boundaries of the median valley along nearly all parts of the Mid-Atlantic Ridge investigated to date. In this particular area, the faulting is especially subdued, and in fact, in profile this part of the Mid-Atlantic Ridge does not have a distinct median valley. Instead, it is characterized by an area of rugged ridges and troughs. These faults are responsible for the stair-step morphology of the area and the lineated backscatter patterns seen in side-scan sonar images.

\section{Serpentinite Exposures in Slow-Spread Crust}

Examination of the southern wall of the Kane Transform just to the north may provide a cross-sectional window into the crust produced at this part of the Mid-Atlantic Ridge from 0 to $\sim 4 \mathrm{Ma}$. In addition to strike-slip fault zones, it shows a complexly faulted, heterogeneous assemblage of variably deformed and metamorphosed gabbroic and ultramafic rocks cut by dikes and major normal-slip shear zones (Auzende et al., 1993). This suggests a history of laterally spreading hydrated upper mantle rocks punctuated by small, isolated mafic plutons to mafic assemblages several kilometers thick, a far cry from the simple, stratiform geology traditionally inferred for the oceanic crust. The serpentinite exposures of the MARK area may represent an interval of seafloor spreading like some of those seen in the walls of the Kane Transform where little if any mafic magmatic material is added to a serpentinite crust converted from laterally spreading upper mantle. If this is typical of slow-spreading ridges with low magma budgets, such serpentinite exposures may be very widespread in slow-spread crust.

Recent studies suggest that serpentinite exposures are associated with segment boundaries that may migrate along spreading centers to produce oblique "wakes" extending into older lithosphere from the spreading axis (Cannat et al., 1995; Gente et al., 1995). These lineaments appear to be associated with bathymetric depressions, RBMA highs, and serpentinite exposures even many kilometers away from the ridge axis. Serpentinite outcrops in the MARK area occur in the segment boundary zone as well as along the edge of a well-defined ridge segment. Outcrops along the median valley walls of the segment just south of the Kane Transform stretch from areas with relatively thin crust to areas of normal crust (Morris and Detrick, 1991). In addition, the serpentinites appear to lack oblique structures that typify ridge-axis discontinuities. Therefore, it appears that the serpentinite exposures of the MARK area are not limited to segment boundaries or oblique lineaments and may be the result of processes that are common along at least some magma-starved segments of slow-spreading ridges.

\section{CONCLUSIONS}

Serpentinized peridotites in the MARK area crop out extensively along the western median valley wall of the northern spreading segment and adjacent segment boundary to the south. Surface studies have been carried out using submersibles, deep-towed cameras, sidescan sonar, and dredges. These studies, in conjunction with ODP drill-core data, provide important constraints on the tectonic setting and mode of exposure of these exhumed upper mantle rocks as well as surrounding crustal materials. Together they reveal the shallow three-dimensional geological architecture of crust produced in a slow-spreading environment.

The integrated structural data along the serpentinite belt do not support a diapiric origin for these hydrated upper mantle rocks, and instead suggest that they have been tectonically unroofed by crustallevel normal faulting. The amount of magmatic crustal material, if any, that has been stripped from above these exposures is not known, but might be constrained by future crustal studies along a seafloor spreading flow line through this area. The serpentinites appear to have been exposed during an interval of essentially amagmatic plate separation in which very little magmatic crust was produced and major detachment faulting occurred. Intermittent volcanic eruptions produced at least a local basaltic cap over the serpentinites. In the northern spreading segment, a recent magmatic event constructed a massive neovolcanic ridge surmounted by the Snake Pit Hydrothermal Vents. The plutonic foundation of this edifice would have intruded and truncated the serpentinite terrain if it once extended into the median valley floor. The serpentinites crop out along the western median valley wall of a well-defined spreading segment, as well as in the adjacent segment boundary. Therefore, they are not limited to segment boundaries or oblique structures as suggested by some recent studies.

\section{ACKNOWLEDGMENTS}

The authors thank the Leg 153 engineering, technical, and scientific staff for their contributions toward the success of this drilling effort. We also thank S.D. Hurst for providing unpublished paleomagnetic data and E. Bonatti and Y. Lagabrielle for very constructive reviews. This work was supported primarily by USSSP grants 1532021 A to J.A. Karson and 153-20822A to R.M. Lawrence for postcruise data analysis. In addition, we thank the National Science Foundation Program in Marine Geology and Geophysics for its support of studies in the MARK area over the last decade. In particular, we acknowledge the support of grants OCE 89-20527 that supported Karson's participation in Nautile Diving programs, and OCE 92-02261 that supported recent Alvin dives near the Leg 153 drill sites.

\section{REFERENCES}

Abbate, E., Bortolotti, V., and Principi, G., 1980. Apennine ophiolites: a peculiar oceanic crust. Ofioliti, 1:59-96.

Aumento, F., and Loubat, H., 1971. The Mid-Atlantic Ridge near $45^{\circ} \mathrm{N}$. XVI. Serpentinized ultramafic intrusions. Can. J. Earth Sci., 8:631-663.

Auzende, J.M., Cannat, M., Gente, P., Henriet, J.P., Juteau, T., Karson, J.A., Lagabrielle, Y., and Tivey, M.A., 1993. A transect through 0-4 Ma oceanic crust: Nautile dives along the Kane Transform. RIDGE Events, 4:310.

Barrett, T.J., and Spooner, E.T.C., 1977. Ophiolite breccias associated with allochthonous oceanic crustal rocks in the East Ligurian Apennines, Italy - a comparison with observations from rifted ocean ridges. Earth Planet. Sci. Lett., 35:79-91.

Batiza R., and Margolis, S.H., 1986. A model for the origin of small nonoverlapping offsets (SNOO's) of the East Pacific Rise. Nature, 320:439441

Bonatti, E., 1976. Serpentinite protrusions in the oceanic crust. Earth Planet. Sci. Lett., 32:107-113.

Bonatti, E., and Hamlyn, P.R., 1981. Oceanic ultramafic rocks. In Emiliani, C. (Ed.), The Sea (Vol. 7): New York (Wiley), 241-283.

Bratt, S.R., and Purdy, G.M., 1984. Structure and variability of oceanic crust on the flanks of the East Pacific Rise between $11^{\circ}$ and $13^{\circ} \mathrm{N}$. J. Geophys. Res., 89:6111-6125.

Brown, J.R., and Karson, J.A., 1988. Variations in axial processes on the Mid-Atlantic Ridge: the median valley of the MARK area. Mar. Geophys. Res., 10:109-138.

Cannat, M., 1993. Emplacement of mantle rocks in the seafloor at mid-ocean ridges. J. Geophys. Res., 98:4163-4172.

Cannat, M., Karson, J.A., Miller, D.J., et al., 1995. Proc. ODP, Init. Repts., 153: College Station, TX (Ocean Drilling Program).

Cannat, M., Mével, C., Maia, M., Deplus, C., Durand, C., Gente, P., Agrinier, P., Belarouchi, A., Dubuisson, G., et al., 1995. Thin crust, ultramafic exposures, and rugged faulting patterns at the Mid-Atlantic Ridge $\left(22^{\circ}-\right.$ $\left.24^{\circ} \mathrm{N}\right)$. Geology, 23:49-52. 
Carlson, R.L., and Herrick, C.N., 1990. Densities and porosities in the oceanic crust and their variations with depth and age. J. Geophys. Res., 95:9153-9170.

Casey, J.F., Dewey, J.F., Fox, P.J., Karson, J.A., and Rosencrantz, E., 1981. Heterogeneous nature of oceanic crust and upper mantle: a perspective from the Bay of Islands Ophiolite Complex. In Emiliani, C. (Ed.), The Sea (Vol. 7) The Oceanic Lithosphere: New York (Wiley), 305-338.

Christensen, N.I., 1992. Seismic velocities. In Carmichael, R.S. (Ed.), Handbook of Physical Properties of Rocks, Volume II: Boca Raton, FL (CRC Press), 1-229.

Coleman, R.G., 1971. Petrologic and geophysical nature of serpentinites. Geol. Soc. Am. Bull., 82:897-918.

Cortosogno, L., Galbiati, B., Principi, G., and Venturelli, G., 1978. La brece ofiolitiche della liguria orientale: nuovi dati e discussione sui modelli paleogeografici. Ofioliti, 3:99-160.

Crane, K., and Ballard, R.D., 1981. Volcanics and structure of the FAMOUS Narrowgate rift: evidence for cyclic evolution: AMAR 1. J. Geophys. Res., 86:5112-5124.

DeLong, S.E., Dewey, J.F., and Fox, P.J., 1977. Topographic and geologic evolution of fracture zones. J. Geol. Soc. London, 136:303-310.

Dengo, C.A., and Logan, J.M., 1981. Implications of the mechanical and frictional behavior of serpentinite to seismogenic faulting. J. Geophys. Res., 86:10771-10782.

Deplus, C., Maia, M., Aslanian, D., and Gente, P., 1992. Segmentation of the Mid-Atlantic Ridge south of Kane fracture zone revealed by gravity anomalies. Results of Seadma 1 cruise. Eos, 73:568.

Detrick, R.S., Buhl, P., Vera, E., Mutter, J., Orcutt, J., Madsen, J., and Brocher, T., 1987. Multi-channel seismic imaging of a crustal magma chamber along the East Pacific Rise. Nature, 326:35-41.

Detrick, R.S., Fox, P.J., Schulz, N., Pockalny, R., Knog, L., Mayer, L., and Ryan, W.B.F., 1988. Geologic and tectonic setting of the mark area. In Detrick, R., Honnorez, J., Bryan, W.B., Juteau, T., et al., Proc. ODP, Init. Repts., 106/109: College Station, TX (Ocean Drilling Program), 15-22.

Detrick, R.S., Honnorez, J., Bryan, W.B., Juteau, T., et al., 1988. Proc. ODP, Init. Repts., 106/109: College Station, TX (Ocean Drilling Program).

Detrick, R.S., Mutter, J.C., Buhl, P., and Kim, I.I., 1990. No evidence from multichannel seismic reflection data for a crustal magma chamber in the MARK area on the Mid-Atlantic Ridge. Nature, 347:61-64.

Dick, H.J.B., 1989. Abyssal peridotites, very slow spreading ridges and ocean ridge magmatism. In Saunders, A.D., and Norry, M.J. (Eds.), Magmatism in the Ocean Basins. Geol. Soc. Spec. Publ. London, 42:71-105.

Dick, H.J.B., Thompson, G., and Bryan, W.B., 1981. Low angle faulting and steady state emplacement of plutonic rocks at ridge-transform intersections. Eos, 62:406.

Escartín, J., Hirth, G., and Evans, B., 1994. Experimental constraints on the strength of serpentine: implications for mid-ocean ridge tectonics. Eos, 75:648.

Fox, P.J., and Gallo, D.G., 1986. The geology of North Atlantic transform plate boundaries and their aseismic extensions. In Tucholke B.E., and Vogt, P. (Eds.), The Western North Atlantic Region. Geol. Soc. Am., DNAG, Vol. N:111-124.

Fox, P.J., and Stroup, J.B., 1981. The plutonic foundation of the oceanic crust. In Emiliani, C. (Ed.), The Sea (Vol. 7): The Oceanic Lithosphere: New York (Wiley), 119-218.

Francis, T.J.G., 1981. Serpentinization faults and their role on the tectonics of slow-spreading ridges. J. Geophys. Res., 86:11616-11622.

Fryer, P., 1992. A synthesis of Leg 125 drilling of serpentine seamounts on the Mariana and Izu-Bonin forearcs. In Fryer, P., Pearce, J.A., Stokking, L.B., et al., Proc. ODP, Sci. Results, 125: College Station, TX (Ocean Drilling Program), 593-614.

Gente, P., Mével, C., Auzende, J.-M., Karson, J.A., and Fouquet, Y., 1991. An example of a recent accretion on the Mid-Atlantic Ridge: the Snake Pit neovolcanic ridge (MARK area: $23^{\circ} 22^{\prime} \mathrm{N}$ ). Tectonophysics, 190:1-29.

Gente, P., Pockalny, R.A., Durand, C., Deplus, C., Maïa, M., Ceuleneer, G., Mével, C., Cannat, M., and Laverne, C., 1995. Characteristics and evolution of the segmentation of the Mid-Atlantic Ridge between $20^{\circ} \mathrm{N}$ and $24^{\circ} \mathrm{N}$ during the last 10 million years. Earth Planet. Sci. Lett., 129:5571.

Gente, P., Zonenshain, L.P., Kuzmin, M., Lisitsin, A.P., Bogdanov, Y.A., and Baronov, B.V., 1989. Géologie de l'axe de la dorsale médio-Atlantique entre 23 et $26^{\circ} \mathrm{N}$ : résultats préliminaires de la $15^{\circ}$ me campagne du N/O Akademik Mstyslav Keldysh (mars-avril 1988). C.R. Acad. Sci. Ser. 2 , 308:1781-1788.
Grindlay, N.R., Fox, P.J., and Macdonald, K.C., 1991. Second-order ridge axis discontinuities in the South Atlantic: morphology, structure, and evolution. Mar: Geophys. Res., 13:21-49.

Hess, H.H., 1962. History of ocean basins. In Buddington, A.F., Engel A.E.J., et al. (Eds.), Petrologic Studies, Geol. Soc. Am. Mem., Buddington Volume, 599-620.

Juteau, T., Berger, E., and Cannat, M., 1990. Serpentinized, residual mantle peridotites from the M.A.R. median valley, ODP Hole $670 \mathrm{~A}\left(21^{\circ} 10 \mathrm{~N}\right.$, $45^{\circ} 02 \mathrm{~W}$, Leg 109): primary mineralogy and geothermometry. In Detrick, R., Honnorez, J., Bryan, W.B., Juteau, T., et al., Proc. ODP, Sci. Results, 106/109: College Station, TX (Ocean Drilling Program), 27-45.

Juteau, T., Cannat, M., and Lagabrielle, Y., 1990. Serpentinized peridotites in the upper oceanic crust away from transform zones: a comparison of the results of previous DSDP and ODP Legs. In Detrick, R., Honnorez, J., Bryan, W.B., Juteau, T., et al., Proc. ODP, Sci. Results, 106/109: College Station, TX (Ocean Drilling Program), 303-308.

Kappel, E.S., and Ryan, W.B.F., 1986. Volcanic episodicity and a non-steady state rift valley along Northeast Pacific spreading centers: evidence from SeaMARC I. J. Geophys. Res., 91:13925-13940.

Karson, J.A., 1990. Seafloor spreading on the Mid-Atlantic Ridge: implications for the structure of ophiolites and oceanic lithosphere produced in slow-spreading environments. In Malpas, J., Moores, E.M., Panayiotou, A., and Xenophontos, C. (Eds.), Ophiolites: Oceanic Crustal Analogues: Proc. Symp. "Troodos 1987": Nicosia, Cyprus (Minist. Agric. Nat. Resour.), 547-555.

1991. Accommodation zones and transfer faults: integral components of Mid-Atlantic Ridge extensional systems. In Peters, U.J., Nicolas, A., and Coleman, R.G. (Eds.), Ophiolites Genesis and Evolution of Oceanic Lithosphere: Dordrecht (Kluwer Academic), 21-37.

Karson, J.A., and Dick, H.J.B., 1983. Tectonics of ridge-transform intersections at the Kane Fracture Zone. Mar. Geophys. Res., 6:51-98.

Karson, J.A., and Fox, P.J., 1986. Geological and geophysical investigation of the Mid-Cayman spreading centre; seismic velocity measurements and implications for the constitution of layer 3. Geophys. J. R. Astron. Soc., $85: 389-411$.

Karson, J.A., Thompson, G., Humphris, S.E., Edmond, J.M., Bryan, W.B. Brown, J.R., Winters, A.T., Pockalny, R.A., Casey, J.F., Campbell, A.C. Klinkhammer, G., Palmer, M.R., Kinzler, R.J., and Sulanowska, M.M. 1987. Along-axis variations in seafloor spreading in the MARK area Nature, 328:681-685.

Karson, J.A., and Winters, A.T., 1992. Along-axis variations in tectonic extension and accommodation zones in the MARK area, Mid-Atlantic Ridge $23^{\circ}$ N. In Parsons, L.M., Murton, B.J., and Browning, P. (Eds.) Ophiolites and their Modern Oceanic Analogues. Geol. Soc. Spec. Publ. London, 60:107-116.

Kelley, D.S., and Delaney, J.R., 1987. Two-phase separation and fracturing in mid-ocean ridge gabbros at temperatures greater than $700^{\circ} \mathrm{C}$. Earth Planet. Sci. Lett., 83:53-66.

Komor, S.C., Grove, T.L., and Hébert, R., 1990. Abyssal peridotites from ODP Hole $670 \mathrm{~A}\left(21^{\circ} 10^{\prime} \mathrm{N}, 45^{\circ} 02^{\prime} \mathrm{W}\right)$ : residues of mantle melting exposed by non-constructive axial divergence. In Detrick, R., Honnorez, J., Bryan, W.B., Juteau, T., et al., Proc. ODP, Sci. Results, 106/109: College Station, TX (Ocean Drilling Program), 85-101.

Kong, L.S.L., Detrick, R.S., Fox, P.J., Mayer, L.A., and Ryan, W.F.B., 1988. The morphology and tectonics of the MARK area from Sea Beam and MARC 1 observations (Mid-Atlantic Ridge $23^{\circ} \mathrm{N}$ ). Mar. Geophys. Res., 10:59-90.

Kong, L.S.L., Solomon, S.C., and Purdy, G.M., 1992. Microearthquake characteristics of a mid-ocean ridge along axis. J. Geophys. Res., 97:16591685 .

Lagabrielle, Y., and Cannat, M., 1990. Alpine Jurassic ophiolites resemble the modern central Atlantic basement. Geology, 18:319-322.

Langmuir, C.H., Bender, J.F., and Batiza, R., 1986. Petrological and tectonic segmentation of the East Pacific Rise, $5^{\circ} 30 \mathrm{~N}-14^{\circ} 30^{\prime} \mathrm{N}$. Nature, 322:422-429.

Lemoine, M., Boillot, G., and Tricart, P., 1987. Ultramafic and gabbroic ocean floor of the Ligurian Tethys (Alps, Corsica, Apennines): in search of a genetic model. Geology, 15:622-625.

Lewis, B.T.R., 1983. The process of formation of ocean crust. Science, 220:151-157.

Lin, J., Purdy, G.M., Schouten, H., Sempéré, J.-C., and Zervas, C,, 1990. Evidence from gravity data for focussed magmatic accretion along the Mid-Atlantic Ridge. Nature, 344:627-632. 
Lister, G.S., and Davis, G.A., 1989. The origin of metamorphic core complexes and detachment faults formed during Tertiary continental extension in the Northern Colorado River region, U.S.A. J. Struct. Geol., 11:65-94.

Macdonald, K.C., and Fox, P.J., 1983. Overlapping spreading centers: new accretion geometry on the East Pacific rise. Nature, 302:55-57.

Macdonald, K.C., Fox, P.J., Perram, L.J., Eisen, M.F., Haymon, R.M., Miller, S.P., Carbotte, S.M., Cormier, M.-H., and Shor, A.N., 1988. A new view of the mid-ocean ridge from the behaviour of ridge-axis discontinuities. Nature, 335:217-225.

Marks, N.S., 1981. Sedimentation of new oceanic crust: the Mid-Atlantic Ridge at $37^{\circ}$ N. Mar. Geol., 43:65-82.

Mével, C., Cannat, M., Gente, P., Marion, E., Auzende, J.-M., and Karson, J.A., 1991. Emplacement of deep crustal and mantle rocks on the west median valley wall of the MARK area (MAR $23^{\circ} \mathrm{N}$ ). Tectonophysics, 190:31-53.

Miyashiro, A., Shido, F., and Ewing, M., 1969. Composition and origin of serpentinites from the Mid-Atlantic Ridge, $24^{\circ}$ and $30^{\circ} \mathrm{N}$ latitude. Contrib. Mineral. Petrol., 23:117-127.

Moores, E.M., and Vine, F.J., 1971. The Troodos Massif, Cyprus and other ophiolites as oceanic crust: evaluation and implications. Philos. Trans. $R$. Soc. London A, 268:443-466.

Morley, C.K., Nelson, R.A., Patton, T.L., and Munn, S.G., 1990. Transfer zones in the East African Rift System and their relevance to hydrocarbon exploration in rifts. AAPG Bull., 74:1234-1253.

Morris, E., and Detrick, R.S., 1991. Three dimensional analysis of gravity anomalies in the MARK area (MAR, $\left.23^{\circ} \mathrm{N}\right)$. J. Geophys. Res., 96:43554366.

Morris, E., Detrick, R.S., Minshull, T.A., Mutter, J.C., White, R.S., Su, W., and Buhl, P., 1993. Seismic structure of oceanic crust in the western North Atlantic. J. Geophys. Res., 98:13879-13903.

Mutter, J.C., and Karson, J.A., 1992. Structural processes at slow-spreading ridges. Science, 257:627-634.

Nicolas, A., 1989. Structure of Ophiolites and Dynamics of the Oceanic Lithosphere: Dordrecht (Kluwer).

O'Hanley, D.S., 1992. Solution to the volume problem in serpentinization. Geology, 20:705-708.

Pinet, N., Lagabrielle, Y., and Whitechurch, H., 1989. Le complexe du Pic des Lauzes (Haut Queyras, Alpes occidentales, France): structures alpines et océaniques dans un masif ophiolitique de type liguro-piémontais. Bull. Soc. Geol. Fr., 8:317-326.

Purdy, G.M., and Detrick, R.S., 1986. Crustal structure of the Mid-Atlantic Ridge at $23^{\circ} \mathrm{N}$ from seismic refraction studies. J. Geophys. Res., 91:3739-3762.

Purdy, G.M., Rabinowitz, P.D., and Schouten, H., 1979. The Mid-Atlantic Ridge at $23^{\circ} \mathrm{N}$ : bathymetry and magnetics. In Melson, W.G., Rabinowitz, P.D., et al., Init. Repts. DSDP, 45: Washington (U.S. Govt. Printing Office), 119-128.

Purdy, G.M., Sempéré, J.-C., Schouten, H., Dubois, D.L., and Goldsmith, R., 1990. Bathymetry of the Mid-Atlantic Ridge, $24^{\circ}-31^{\circ} \mathrm{N}$ : a map series. Mar. Geophys. Res., 12:247-252.

Raleigh, C.B., and Patterson, M.S., 1965. Experimental deformation of serpentinite and its tectonic implications. J. Geophys. Res., 76:3965-3985.
Reinen, L.A., Weeks, J.D., and Tullis, T.E., 1991. The frictional behavior of serpentinite: Implications for aseismic creep on shallow crustal faults. Geophys. Res. Lett., 18:1921-1924.

Rosendahl, B.R., Reynolds, D.J., Lorber, P.M., Burgess, C.F., McGill, J., Scott, D., Lambiase, J.J., and Derksen, S.J., 1986. Structural expressions of rifting: lessons from Lake Tanganyika, Africa. In Frostick, L.E., Renaut, R.W., Reid, I., and Tiercelin, J.-J. (Eds.), Sedimentation in the African Rifts. Geol. Soc. Spec. Publ. London, 25:29-43.

Schouten, H., and White, R.S., 1980. Zero offset fracture zones. Geology, 8:175-179.

Schulz, N.J., Detrick, R.S., and Miller, S.P., 1988. Two- and three-dimensional inversions of magnetic anomalies in the MARK area (Mid-Atlantic Ridge, $23^{\circ} \mathrm{N}$ ). Mar. Geophys. Res., 10:41-57.

Sempéré, J.-C., Purdy, G.M., and Schouten, H., 1990. Segmentation of the Mid-Atlantic Ridge between $24^{\circ} \mathrm{N}$ and $30^{\circ} 40^{\prime} \mathrm{N}$. Nature, $344: 427-431$.

Shih, J.S.-F., 1980. The nature and origin of fine-scale sea-floor relief. [Ph.D. dissert.]. MIT/WHOI Joint Program in Oceanography.

Stakes, D.S., Shervais, J.W., and Hopson, C.A., 1984. The volcanic-tectonic cycle of the FAMOUS and AMAR valleys, Mid-Atlantic Ridge $\left(36^{\circ} 47^{\prime} \mathrm{N}\right)$ : evidence from basalt glass and phenocryst compositional variations for a steady state magma chamber beneath the valley mid-sections, AMAR 3. J. Geophys. Res., 89:6995-7028.

Stroup, J.B., and Fox, P.J., 1981. Geologic investigations in the Cayman Trough: evidence for thin oceanic crust along the Mid-Cayman Rise. $J$. Geol., 89:395-420.

Tartarotti, P., Mével, C., and Cannat, M., 1995. Gabbroic intrusions in serpentinized peridotites from the Mid-Atlantic Ridge at $23^{\circ} \mathrm{N}$. In Nicolas, A., and Vissers, E. (Eds.), Mantle Denudation in Slow-spreading Ridges and Ophiolites: New York (Kluwer Acad. Publ.).

Toomey, D.R., Purdy, G.M., Solomon, S.C., and Wilcock, W.S.D., 1990. The three-dimensional seismic velocity structure of the East Pacific Rise near latitude $9^{\circ} 30 \mathrm{~N}$. Nature, 347:639-645.

Toomey, D.R., Solomon, S.C., Purdy, G.M., and Murray, M.H., 1988 Microearthquakes beneath the median valley of the Mid-Atlantic Ridge near $23^{\circ} \mathrm{N}$ : tomography and tectonics. J. Geophys. Res., 93:9093-9112.

Tucholke, B.E., and Lin, J., 1994. A geological model for the structure of ridge segments in slow-spreading ocean crust. J. Geophys. Res., 99:11937-11958

Vera, E.E., Mutter, J.C., Buhl, P., Orcutt, J.A., Harding, A.J., Kappus, M.E., Detrick, R.S., and Brocher, T.M., 1990. The structure of 0- to 0.2-m.y. old oceanic crust at $9^{\circ} \mathrm{N}$ on the East Pacific Rise from expanded spread profiles. J. Geophys. Res., 95:15529-15556.

Wernicke, B., and Burchfiel, B.C., 1982. Modes of extensional tectonics. J. Struct. Geol., 4:105-115.

Winters, A.T., 1989. Extensional faulting in the MARK area. [M.S. thesis]. Duke Univ., Durham, NC.

Date of initial receipt: 19 July 1995

Date of acceptance: 5 March 1996

Ms 153SR-001 